\begin{tabular}{|c|c|c|c|}
\hline & $\begin{array}{l}\text { FATIH } \\
\text { SULTAN } \\
\text { MEHMET } \\
\text { VAKIF ÜNivERSiTESi }\end{array}$ & $\begin{array}{l}\text { FSM İlmî Araştırmalar Insan ve Toplum Bilimleri Dergisi } \\
\text { FSM Scholarly Studies Journal of Humanities and Social Sciences } \\
\text { Sayı/Number } 18 \text { Yıl/Year } 2021 \text { Güz/Autumn } \\
\text { C } 2021 \text { Fatih Sultan Mehmet Vakıf Üniversitesi }\end{array}$ & aris \\
\hline DOI: & & http://dergipark.org.tr/fsmia & http://dergi.fsm.edu.tr \\
\hline Araştır & lesi / Research Article & Geliş Tarihi / Received: 01.04.2021 Kabul Tarihi / Accepted: 19.05.2021 & FSMIAD, 2021; (18): 251-286 \\
\hline
\end{tabular}

\title{
Sosyal Hizmet Uygulamalarında Sosyal Rol Valörizasyon Kuramı: Osmanlıda İşitme ve Görme Engelliler Örneği
}

\author{
Selahattin Aydın* \\ Recep Yıldız
}

\section{Öz}

Sosyal Rol Valörizasyon (SRV) Kuramı çeşitli sosyal kategorilere yerleştirilen bireylerin farklılıkları sebebiyle sosyal değersizleştirilme ve değersiz rollerle ilişkilendirilme süreçlerini açıklamaya yönelen bir yaklaşımdır. SRV Kuramı değersizleştirilmiş bir kategori olarak engellilerin, içinde yaşadıkları toplumca muteber sayılan sosyal roller ifa edebilme kapasitelerinin geliştirilmesi yoluyla toplumsal konumlanışlarının olumlu yönde değişeceğini önermektedir. Çalışmada SRV yaklaşımının önermeleri ile engellilik olgusunun Türk toplumundaki anlamlandırılma formları arasında ilişki bulunduğunu; SRV kuramının bir sosyal hizmet uygulama yaklaşımı olarak kullanılmasının ihtiyaç duyduğu sosyokültürel zeminin Türk toplumunda mevcut bulunduğunu ve özellikle Osmanlı döneminde işitme engellilerin devlet kurumlarında istihdamları, görme engellilerin din hizmetleri ve hafızlık müessesesinde istihdamları gibi örneklerle ortaya koyma amacındadır.

Anahtar Kelimeler: Sosyal rol valörizasyon kuramı, sosyal rol, engellilik, işitme engelli, görme engelli.

\footnotetext{
* Dr, İstanbul/Türkiye, selahattinaydin2006@gmail.com, orcid.org/0000-0002-5031-9066.

** Doç. Dr., Bandırma Onyedi Eylül Üniversitesi Sağlık Bilimleri Fakültesi Sosyal Hizmet Bölümü, Balıkesir/Türkiye, ryildiz@bandirma.edu.tr, orcid.org/0000-0003-0584-6649.
} 


\title{
Social Role Valorization Theory in Social Service Applications Implementations: The case of Deafs and Blinds in the Ottoman Empire
}

\begin{abstract}
Social Rol Valorization (SRV) theory is an approach intending to explicate the processes which socially devaluate those individuals located in various social kategories, and designate them with devalued roles due to their differences. SRV Theory proposes that social positions of disabled persons, as being devalued category, can glow up by improving their capacity to undertake such social roles valued by the society they live in. This study aims to demonstrate that there is a remarkable relevance between forms of interpretation of disability in Turkish society and the main propositions of SRV Theory; Turkish society holds the proper socio-cultural background required SRV theory to be utilized as a socialwork implementation approach. These views have been discussed by holding up the employment of deaf individuals in state agencies and employment of blind individuals in religious services and Quran memorization sector in Ottoman period as examples.
\end{abstract}

Keywords: Social rol valorization theory, social role, disability, deaf, blind. 


\section{Giriş}

Toplum bireylerin kurumlar, kurallar ve normlar eliyle ortak zeminlerde bir araya gelmeleriyle oluşmasına rağmen bireylerin toplamından daha fazla bir anlama sahiptir. Loudfoot'un ifadesiyle toplumları salt birer insan yığınları olmaktan kendi içerisinde bütünlük arz eden yapılara dönüştüren temel vasıf, sahip olduğu kurumlar ve ilişki paternleriyle fertleri birbirine bağlama gücüdür. ${ }^{1}$ Din, gelenek-görenek ve aile gibi kurumlar toplumsal düzeni üretirken, normlar ve kurallar da bu düzenin devamlılığını koruma fonksiyonu görür. Bu kompozisyon içerisinde toplumu meydana getiren her birey bir sosyal statüde konumlandırı11r. Bu konumlandırılış bireye üstlendiği statüyle ilişkili sorumluluklar (roller) de yükler. Annelik, babalık, öğretmenlik, vatandaşlık gibi üstlendiğimiz birçok rol aynı zamanda bu rollere ilişkin ortaya koymamız beklenen davranış paternlerinin de kodlarını bünyelerinde barındırır. ${ }^{2}$ Başka deyişle rol üstlenmek, bireyi içinde yaşadığ1 toplumun kurumlarınca üretilmiş beklendik formlarla davranmaya zorlar. ${ }^{3}$ Roller bu yönüyle tipik birer davranış kalıpları olarak da tanımlanabilir. ${ }^{4}$ Birey sosyal alana adımını attığı an itibarıyla bir veya daha fazla rolün aktörü olmakla karşı karşıyadır veya sosyal bir varlık olabilme vasfını ancak üstlendiği roller üzerinden realize edebilir. ${ }^{5}$ Her bir bireyin sosyal bir aktör olabilme vasfinı üstlendiği roller aracılığıyla kazanması, sosyal ilişkileri bir tür rol ilişkilerine dönüştürmüş olur. ${ }^{6}$ Loudfoot "roller iş bölümünün adıyken, iş bölümü bireyleri toplumsal dayanışmada bulunmaya muktedir kılar" derken sosyal ilişkilerin birer rol ilişkisi olma özelliğinden söz etmektedir. Diğer taraftan Loudfoot'un bu tespiti, bireyin toplumsal işleyiş içerisinde bir fonksiyonu yerine getirebilmesinin, toplumsal alandaki varlığının anlama kavuşmasını üstlenen roller yoluyla mümkün olduğu îmâsını barındırmaktadır. Roller bireyi toplumsal düzenin işleyişine katkı sağlayan işlevsel birer aktör kılarken, onun sosyal konumlanışı da rolleri,

1 E. M. Loudfoot, "The Concept of Social Role", Philosophy of the Social Sciences, cilt 2, say1 1, 1972, s. 34.

2 J. E. Stets, "Role Identities and Person Identities: Gender Identity, Mastery Identity, and Controlling One's Partner", Sociological Perspectives, cilt 38, say1 2, 1995, s. 130.

3 S. D. Sieber, "Toward a Theory of Role Accumulation", American Sociological Review, cilt 39, say1 4, 1974, s. 567.

4 B. J. Biddle, "Recent Developments in Role Theory", Annual Review of Sociology, cilt 2, say1 1, 1986, s. 67.

5 R. H. Turner, "The Role and the Person", American Journal of Sociology, say1 84, 1978, s. 2.

6 P. A. Thoits, "Multiple İdentities and Psychological Well-Being: A Reformulation and Test of the Social İsolation Hypothesis", American Sociological Review, cilt 48, say1 2, 1983, s. 175.

7 Loudfoot, a.g.m., s. 33. 
yani işlevi üzerinden belirlenir. ${ }^{8}$ Örneğin bazı sosyal roller üstlenenlere toplumsal düzen içerisinde öncelikler veya avantajlar sağlarken, aynı zamanda davranışlara da bir dizi sinırlamalar getirebilir. ${ }^{9}$

Rollerin tek anlamı bireyi sosyal düzenin işleyiş̧ine katkı sağlayan bir aktör kılmakla sınırlı değildir. Birey kendisini anlamlı bir sosyal aktör olarak algılama bilincine paralel olarak kimliğini de üstlendiği roller vasatında dâhil olduğu rol ilişkileri yoluyla edinir ve sürdürülebilir kılar. ${ }^{10}$ Bir başka deyişle roller aynı zamanda birer kimlik olma vasfiyla bireyin sosyal arenadaki varlığının bir başka veçhesini teşkil eder. ${ }^{11}$ Bireylerin kim oldukları sorusunu üstlendikleri rolleri referans alarak cevaplama motivasyonlarında hiç şüphesiz kimlik tanımlayıc1s1 olarak görülen rollere atfedilen toplumsal değerin önemli bir yeri vardır. $\mathrm{Bu}$ meyanda engellilik benzeri değersizleştirilmiş kimlikler üstlenmek durumunda olan bireylerin kendi kimliklerini üstlendikleri rolleri merkeze alarak tanımlama motivasyonları daha da belirginleşebilmektedir. Nitekim Dorozenko, Roberts ve Bishop, zihinsel engelliliğin sosyal inşa süreçlerini, katılımcıların kendi kimlik tanımlamaları ile üstlendikleri sosyal roller/rol ilişkileri bağlamında ele alan bir çalışma gerçekleştirmişlerdir. Çalışma, değersizleştirilmiş zihinsel engellilik kimliğiyle etiketlenen bireylerde, kendi kimlik tanımlamalarında ağırlıklı olarak üstlendikleri sosyal rolleri öne çıkarma eğiliminin var olduğunu ortaya koymuştur. ${ }^{12} \mathrm{O}$ halde sosyal roller, bireyin toplumsal düzen içerisindeki konumunu belirleme gücüyle paralel olarak değersizleştirici kimlikleri etkisiz kılma aracına da dönüşebilmektedir. Birey, içinde yaşadığı toplumun muteber saydığı rolleri üstlenmek yoluyla kendi zihin dünyasında tanımladığı ideal kimliği tehdit eden değersizleştirici etiketleri bertaraf ederek kendisini muteber sayılan bir yerde konumlandırmaya yönelmektedir.

8 R. L. Allen - L Waks, "The Social Reality Construction of Attitudes Toward the Social Roles of Women and African Americans", Howard Journal of Communications, cilt 2, say1 2, 1990, s. 170.

9 C. S. Ang - P Zaphiris, "Social Roles of Players in MMORPG Guilds", Information, Communication \& Society, cilt 13, say1 4, 2010, s. 593.

10 Thoits, a.g.m., s. 175.

11 D. Daukantaite - E S Thompson, "The Relationship Between Identity Consistency Across Social Roles and Different Aspects of Mental Health Varies by Age Group", Identity, cilt 14, say1 2, 2014, s. 82; A. Pierro - L. Mannetti - S. Livi, "Self-Identity and the Theory of Planned Behavior in the Prediction of Health Behavior and Leisure Activity", Self and Identity, cilt 2, say1 1, 2003, s. 48; J. E. Stets - P. J. Burke, "Identity Theory and Social Identity Theory", Social Psychology Quarterly, cilt 63, say1 3, 2000, s. 226; Stets, a.g.m. s. 129.

12 K. P. Dorozenko - L. D. Roberts - B. Bishop, "The İdentities and Social Roles of People with an İntellectual Disability: Challenging Dominant Cultural Worldviews, Values and Mythologies", Disability \& Society, cilt 30, say1 9, 2015, s. 1350. 
Sosyal rollerin buraya kadar değinilen majör fonksiyonları (bireyi sosyal düzenin işlevsel bir bileşeni yapma, sosyal konumlanışını tayin etme ve bireyin kimliğini yapılandırma gibi), engelli bireylerin rol üstlenme kabiliyetlerinin geliştirilmesi yoluyla sosyal değersizleştirme süreçlerinden korunmalarını amaçlayan SRV Kuramının önerilmesine ilham kaynağı olmuştur. SRV Kuramı, acı tecrübelerden sonra engelli kesimlerin hak arayışı mücadelesine giriştikleri bir atmosferde önerilmiştir. Özellikle, batı dünyasının binlerce insanı engellerinden dolayı hayattan koparan ve sistematik bir şekilde kısırlaştırma uygulamalarına tabi tutarak içinde "defolu bireylerin" olmadığ 1 "steril bir toplum" meydana getirmeyi amaçlayan Öjeni Hareketi ile işitme engelli bireyleri duyabilen bireyler gibi konuşmaya zorlayan Oralist Hareket bu acı tecrübelerdendir. Kuram, değerli roller üstlenmenin -başta engelliler olmak üzere- sosyal değersizleştirmeye muhatap olan kesimlerin sosyal saygınlıklarını ve hayat kalitelerini yükselteceği varsayımına dayanmaktadır. Ampirik bilgi ile pratik uygulamalar arasında bir ilişki oluşturmayı amaçlayan kuram, engellilere yönelik hizmetler ile kurumların yeniden yapılandırılmasında belli ölçülerde anlayış değişikliğine sebep olmuştur.

Bireylerin toplumsal yaşam içerisinde üstlendikleri roller ile bu rolleri üstlenenlere atfedilen değer ve algılar toplumdan topluma değişiklik gösterir. Bu bağlamda engelli bireylerin değerli roller üstlenmelerinin hayat kalitelerine, bireysel ve toplumsal saygınlıklarına olan yansımaları da içinde yaşadıkları toplumun inanç, değer ve geçmiş dönem tecrübeleriyle yakından ilişkilidir. Bu bağlamda çalışma;

- Türk toplumunun, engellilere değerli roller yükleme ve bedensel farkl1lıkları bu roller vasitasıyla avantaja dönüştürebilme konusunda bir sosyokültürel hafızaya

- Türk toplumunun, SRV kuramının bir sosyal hizmet uygulama yaklaşımı olarak etkin şekilde kullanılmasını mümkün kılabilecek bir karaktere sahip olduğu iddiasını taşımaktadır.

Yine çalışma tartıştığ iddiasını SRV kuramının temel varsayımları ile ilişkili bir şekilde Osmanlı dönemindeki örnek iki uygulama ile temellendirmektedir.

- İşitme engellilerin çeşitli devlet kurumlarında istihdamları

- Görme engellilerin din hizmetleri ve hafızlık müessesesinde istihdamları.

Uygulamanın ortaya koyduğu sonuçları da iki maddede toplamaktadır.

- Engelli bireylerin bedensel farkl11ıklarının hem devlet ve toplum hem de engelli bireyler açısından bir avantaja dönüştürülme anlayışını ortaya çıkarmaktadır. 
- Engelli bireylerin hayat kalitelerini ve sosyal itibarlarını yükseltmesi bakımından da önemli bulunmuştur.

Çalışmanın ilk bölümünde sosyal rollerin kavramsal ve kuramsal çerçevesi ana hatlarıyla ortaya konulmuş; bir sonraki bölümde SRV kuramının temel varsayımları ve önermeleri ele alınmış, ardından da Osmanlı döneminde işitme engellilerin devlet kurumlarında, görme engellilerin din hizmetleri ve hafızlık müessesesinde istihdamlarına ilişkin örnek uygulamalara yer verilmiştir. Çalışmanın son bölümü ise SRV kuramının Türkiye'deki engellilere yönelik sosyal hizmet uygulamalarının geliştirilip çeşitlendirilmesinde oynayabileceği role ilişkin değerlendirmeler ile önerileri ihtiva etmektedir.

\section{Sosyal Rollerin Kuramsal ve Kavramsal Çerçevesi}

Bireylerin üstlendikleri rollerin gücü (başkalarıyla olan ilişkilerini, davranışlarını, kimliklerini, kısacası sosyal alandaki varlıklarını etkileyen gücü), rol kavramının birçok sosyal bilim dalının ilgi alanına girmesi sonucunu doğurmuştur. Sosyoloji, sosyal psikoloji, antropoloji gibi sosyal bilim dallarında rolleri ele alan çok sayıda çalışmaya rastlamak mümkündür. Rollerin farklı disiplinler tarafindan ele alınan anahtar bir kavram olması, Biddle, Handel, Hilbert gibi yazarların da ifade ettiği üzere bu kavram üzerinde bir konsensüs oluşmasını güçleştirmektedir. ${ }^{13}$ Nitekim Biddle bu kavram üzerinde bir tutarlılı̆̆ın olmayışını, Linton ve Mead gibi görüşleri sosyal kuram dünyasında geniş yankı bulan yazarların rol kavramından aynı şeyi anlamamalarıyla açıklamaktadır. Biddle devamla Linton ve Parsons gibi yapısalcı-fonksiyonalist kuram yazarlarının rolleri sosyal statülerle ilişkili davranış formları olarak tanımlarken; Winship ve Mandel gibi bazı yazarlar açısından rollerin sosyal pozisyon anlamına geldiğini; diğer taraftan Zurcher gibi bazı yazarların da rolleri davranışlarla eşleştirilmiş beklentiler olarak anladığına dikkat çekmektedir. ${ }^{14}$ Anlaşılacağı üzere sosyal bilimlerin ana akım kuramları rollerin kavramsal çerçevesine ilişkin çeşitlilik arz eden yaklaşımlar önermişlerdir. Bu çalışmada rollerin kavramsal çerçevesi Yaptsalct-Fonksiyonalist, Sembolik Etkileşim ve Bilişsel kuramların bakış açıları temelinde ele alınmıştır.

Sosyal rollerle ilgilenen kuramcilar genel itibarıla rol kavramını, sosyal hayatı bir tür tiyatro sahnesi ve bireyi de bir aktör olarak farz eden tiyatro metafo-

13 Biddle, a.g.m. s. 67-68; W Handel, "Normative Expectations and the Emergence of Meaning as Solutions to Problems: Convergence of Structural and Interactionist Views", American Journal of Sociology, cilt 84, say1 4, 1979, s. 855; R A Hilbert, “Toward an İmproved Understanding of "Role", Theory and Society, cilt 10, say1 2, 1981, s. 208.

14 Biddle, a.g.m. s. 68. 
ru üzerinden irdelemeye yönelmişlerdir. ${ }^{15} \mathrm{Bu}$ tiyatro metaforunun rollerle ilgili literatürde geniş bir kabul görmesinde iki ön kabul etkili olmaktadır. Birincisi rollerin ve onlarla ilişkili davranış kalıplarının sosyal yapılarca üretilmiş olduğunun varsayılmasıdır. İkincisi de belli rolleri üstlenen bireylerin belli davranışları sergileyeceklerinin bir başka deyişle rollerin davranışlarla sıkı bir sebep-sonuç ilişkisi içerisinde olduğunun varsayılmasıdır.

\section{a. Yapısalcı-Fonksiyonalist Kuramda Rol}

Rol kavramının 1930'lu yılların başından itibaren yoğunluklu olarak tartışılmaya başlandığı görülmektedir. ${ }^{16} \mathrm{Bu}$ kavramın sosyal bilimcilerin gündemine taşınmasına öncülük eden kuramcılardan olan Ralph Linton' ${ }^{17}$ göre sosyal statülerle ilişkili davranış paternleri olan roller, bireysel aksiyonların birer modellerini teşkil ederler; bireyin sahip olduğu statülerin bir veçhesi olmakla öğrenme yoluyla edinilirler. ${ }^{18}$ Linton'un rolleri esas itibarıla toplumsal yaptlarca tanımlanmış ve bir tür kalıplaşmış beklendik davranış formları olarak ele alma yaklaşımı, yapısalcı-fonksiyonalist kuramın rol kavramına dair ileri sürdüğü önermelerin de genel çerçevesini çizmektedir. Ağırlıklı olarak Talcott Parsons tarafindan yapılan fikrî katkılarla şekillenen yapısalcı-fonksiyonalist yaklaşım esas itibarıla sosyal düzenin mekaniğini açıklama problemiyle ilgilenmiştir. Yaklaşımın, önermelerinin merkezine sosyal düzen kavramını yerleştirmesi, toplumsal süreçlerin şekillenmesinde bireyin kurumlara nazaran daha edilgen bir konuma yerleştirilmesini de kaçınılmaz kılmaktadır. Zira yapısalcı-fonksiyonalist kuramcılar açısından rasyonel ve objektif bir mahiyeti olan sosyal gerçeklikler bir düzen içinde vuku bulurken, insan davranışlarının da öngörülebilir ve kontrol altında tutulabilir olmaları gerekir. ${ }^{19}$ Yapısalc1-fonksiyonalist kuramcılarının role ilişkin görüşlerini şöylece özetlemek mümkündür.

Toplum denilen yapı birbiriyle aralarında illiyet bağı bulunan parçaların bir araya getirdiği bir organizma iken; bu organizmayı oluşturan bileşenler işlevleri-

15 L. M. Guirguis - B. A. Chewning, "Role Theory: Literature Review and İmplications for Patient-Pharmacist İnteractions", Research in Social and Administrative Pharmacy, cilt 1, say1 4, 2005, s. 489; S. Jacobs, "How Role Replaced Personality as a Major Category of Sociology", The American Sociologist, cilt 49, say1 2, 2017, s. 281.

16 F. L. Bates, "Position, Role, and Status: A Reformulation of Concepts", Social Forces, cilt 34, say1 4, 1956, s. 313.

17 Bates, a.g.m. s. (istifade edilen sayfanın numarası belirtilmemiştir.); Jacobs, a.g.m. s. 280.

18 M. Daniels, "Relational Status and the Role Concept", The Pacific Sociological Review, cilt 2, say1 1, 1959, s. 43.

19 S. Gabel - S. Peters, "Presage of a Paradigm Shift? Beyond the Social Model of Disability toward Resistance Theories of Disability", Disability \& Society, cilt 19, say1 6, 2004, s. 587. 
ni yerine getirerek organizmanın bir düzen içerisinde varlığını sürdüregelmesini sağlar. ${ }^{20} \mathrm{Bu}$ bağlamda sosyal düzenin birer parçası olan bireylerin davranışları çeşitlilik arz etmekle birlikte durağan bir karaktere sahiptir. Zira bireylerin davranışları vuku buldukları sosyal düzen içerisinde tanımlı bir fonksiyonu yerine getirmekte; aktörler sosyal sistem içerisinde sergiledikleri davranışlarla ilgili ortak tecrübeleri paylaşmaktadır. Bu cümleden olarak roller de stabildirler ve toplulukların üyelerince kabul görmüş sosyal yapıların objektif ve real nitelikleridir. ${ }^{21}$

Roller, toplumsal sistemlerin bireylerden gerçekleștirmesini beklediği davranışlardır. Zira sosyal sistemler bireylere statüler verirken, işgal ettikleri statülere uygun davranışlar sergilemelerini bekler. Uygun olan ve uygun olmayan davranışlar, sosyal sistemlerin kurumlarının yazılı olmayan kurallarıyla (normlarıyla) belirlenir. Aktörlerin rollerini icra etme biçimleri rollerle ilişkilendirilmiş normlarca denetlenirken; aktörlerin normlara olan uyumları ya normları içselleştirip benimsemeleri ya da sosyal sistemin yaptırımlarına maruz kalmalarıyla mümkün olur. Bu çerçevede normlar ve rollerden kaynaklanan davranışlar bireylerin sosyal düzene uyumlarına aracılık eder; birey rolleriyle ilişkili davranışlarının yönelimini belirlemede edilgen bir konumda olmakla esas itibarıyla normlara uyma davranışı gösterme durumundadır. ${ }^{22}$

Rollerin çeşitlenmesi, farklı bireylerin farklı roller üstlenmesi ve icra etmesi yoluyla oluşan sosyal düzeni açıklamada toplumsal eşitsizlikler (yahut farklılıklar) bir tür itici unsurdur. Onlara göre sosyal statüler doğuştan veya sonradan bireysel çabalar yoluyla elde edilmiş olabilirler; bu meyanda bireyler rol icra edebilme kapasitesini de yetenekleri, fiziksel yetileri, eğitimi gibi unsurlar aracılığıyla edinir. Rollerin sosyal statülerle olan bu katı ilişkisi kaçınılmaz olarak bireylerin sosyal düzenin işleyişine katkı verebilmelerini (değerli bir konuma sahip olabilmelerini) rol icra edebilme kapasiteleriyle ilişkili hale getirmektedir. Her rol, onu icra edecek ideal aktörlerin de tanımlanmasını zorunlu kılmaktadır. $\mathrm{Bu}$ zorunluluk toplumun normallik/normal dış1ık kıstaslarının da temel belirleyicisidir.

Engelli bireyler fonksiyonalist kuramın rol kavramına getirdiği açıklamalar bakımından, sahip oldukları fiziksel/mental yeti kayıpları dolayısıyla toplumsal

20 J. H. Chilcott, "Structural Functionalism as a Heuristic Device", Anthropology Education Quarterly, cilt 29, say1 1, 1998, s. 103.

21 P. L. Callero, "Toward A Meadian Conceptualization of Role”, The Sociological Quarterly, cilt 27, say1 3, 1986, s. 346.

22 U. Gerhardt, “Toward a Critical Analysis of Role”, Social Problems, cilt 27, say1 5, 1980, s. 556. 
düzenin sürdürülebilirliğinin bir parçası olmak adına gerekli rolleri icra edebilme kapasitesinden uzak sayılırlar. Bu yönüyle engellilik bir tür normal dişılık ve sosyal sapma durumudur. Böylece engellilik, fiziksel veya mental yeti yitimi olan bireylere atfedilen, atfedildiği bireyleri edilgen ve muhtaç olma etiketleriyle tanımlayan bir sosyal role dönüşür. Engellilik rolünü üstlenmiş bireylerin başkalarına bağımlı olmaları beklenir, engellilikleri bir anlamda onları çocuksu bir niteliğe kavuşturur. Zira Parsons engelliliği hem birey hem de sosyal sistemin işleyişi bakımından sorun olarak anlamaktadır. Ona göre engelli bireylerin (hasta rolü üstlenmiş bireylerin) normal sayılan sosyal rolleri icra etmekten uzak oluşlar1 ya da sosyal düzenin devamlılığına katkı sağlayamama durumları bir sorun olmakla birlikte, içinde bulundukları medikal şartlar dolayısıyla tolare edilebilir bir durumdur. ${ }^{23} \mathrm{Bu}$ durumda engellilik sosyal rollerin yerine getirilmesinden muaf tutulma ve birtakım önceliklere sahip görülme gerekçesine dönüşür. ${ }^{24}$ Engelli bireyler "normal" sayılan bireylerin yerine getirmeleri beklenen sosyal rolleri icra edemeyeceklerinden, kişisel bakım benzeri hayatlarını idame ettirebilecek gündelik aktiviteleri de yerine getirmeleri zor olacaktır; dolayısıyla bakım ve korunmaya ihtiyaç duymaları kaçınılmazdır.

Yapısalc1-Fonksiyonalist kuramın rol kavramını açıklamada başvurduğu önermeler bu kavram etrafında zengin bir literatürün oluşmasına katkı sağlamıştır. Ancak yapısalcı-fonksiyonalist kuramın önermeleri çeşitli eleştirilerle de karşılaşmıştır. ${ }^{25}$ Her şeyden önce iletişim kanallarının her geçen gün daha fazla çeşitlendiği ve coğrafî mesafelerin iletişim araçlarınca ortadan kaldırıldığı bir dünyada yaşadığımız gerçeği göz önünde bulundurulduğunda; bireylerin içinde yaşadıkları sosyal yapıların haricinde daha farklı güç kaynaklarının etkisinde kalmaya daha açık hale geldikleri bir realitedir. Bu durumda 'sosyal normların bireyin davranışları üzerindeki belirleyici etkisi de azalmaya tabidir' demek zor olmayacaktır. Toplumsal yapıların dış etkilere her geçen gün daha açık hale gelmesi, aynı zamanda sosyal sistemlerin yapısalc1-fonksiyonalist kuramın öngördüğü ölçüde statik bir karaktere sahip olup olmadığı sorusunu da akla getirmektedir. Nitekim Inglehart, Norris ve Welzel' in 2003 yılında yayınladıkları 'Dünya Toplumlarının Değerleri Araştırması' (World Values Survey) verilerine dayanarak belirtmiş oldukları üzere; yaşanan siyasî ve ekonomik gelişmeler paralelinde

23 A. Segall, "The Sick Role Concept: Understanding Illness Behavior", Journal of Health and Social Behavior, cilt 17, say1 2, 1976, s. 163.

24 J. C. Burnham, "The Death of the Sick Role", Social History of Medicine, cilt 25, say1 4, 2012, s. 762; S. Levine - M. A. Kozloff, "The Sick Role: Assessment and Overview”, Annual Review of Sociology, cilt 4, say1 1, 1978, s. 317; Segall, a.g.m. s. 163. 
toplumsal değerler de kaçınılmaz bir değişime tabi olurken sosyal roller de yeni tanım ve anlamlara kavuşagelmektedir. ${ }^{26}$ Öte yandan bireylerin süreklilik arz eden her davranışının sosyal düzenlerin işleyişi için bir fonksiyonu yerine getirip getirmediği de başka bir tartışma konusu olarak durmaktadır.

\section{b. Sembolik Etkileşim Kuramında Rol}

Yapısalcı-fonksiyonalist kuramına göre sosyal davranışlar, esas itibarıyla sosyal sistemlerin mekaniği tarafından şekillendirilir iken; sembolik etkileşim kuramına göre sosyal davranışlar, etkileşim bağlamlarının özgün dinamikleri (söylemler ve anlatılar, müzakere edilen kimlikler ve düzenler, beklentiler, hâlihazırda olup bitenlere getirilen yorumlamalar benzeri) üzerinden vücut bulur. ${ }^{27}$ Birey-toplum ilişkisini sosyolojik dinamikler merkezli bir perspektif üzerinden açıklamayı öneren sembolik etkileşim kuramının terminoloji dünyasında "etkileşim" kavramı ağırlıklı bir yer işgal eder ki insanlar arası etkileşimler anlamlarını vuku buldukları kendi tabi mecralarında kazanırlar. ${ }^{28}$ Birey davranışlarını etkileşim içerisinde bulunduğu diğerlerinin beklenti ve davranışları ile de uyum gösterecek bir tarzda gerçekleştirirken; üstlendiği rollerin icaplarını başkalarının alg1 ve yorumlamalarından bağımsız olarak tek başına tayin etme mevkiinde değildir. ${ }^{29} \mathrm{Bu}$ itibarla sembolik etkileşim kuramının önermeleri bakımından rollerin üstlenilmesinde ve yerine getirilmesinde bireyi otonom bir aktör olarak değerlendirmek anlaml değildir. ${ }^{30}$ Birey bir aktör olarak rol üstlenme ve icra süreçlerinde başkalarına ilişkin kendi beklentilerinin yanında, muhataplarının dünyay1 algılama formlarını, geçmiş etkileşim tecrübelerini, içinde bulunduğu bağlamın sembollerini, muhatap olacağı tepkiler benzeri unsurları dikkate almak durumundadir. ${ }^{31}$

26 R. Siemieńska, “Guest Editor's Introduction: Value Systems and Social Roles in CrossNational Perspective", International Journal of Sociology, cilt 38, say1 4, 2008, s. 4 (InglehartNorris-Welzel, World Values Survey, 2003'den akt.).

27 J. Roe - S. Joseph - H. Middleton, "Symbolic İnteraction: A Theoretical Approach to Understanding Stigma and Recovery", Mental Health Review Journal, cilt 15, say1 1, 2010, s. 31.

28 J. Huber, "Symbolic İnteractionism as a Pragmatic Perspective: The Bias of Emergent Theory", American Sociological Review, cilt 38, say1 2, 1973, s. 274.

29 S. Min - L. M. Ceballos - J. Yurchisin, "Role Power Dynamics within The Bridal Gown Selection Process", Fashion and Textiles, cilt 5, say1 1, 2018, s. 1.

30 R. T. Serpe, "Stability and Change in Self: A Structural Symbolic İnteractionist Explanation", Social Psychology Quarterly, say1 50, 1987, s. 44.

31 L. C. Amankwaa, "Maternal Postpartum Role Collapse as a Theory of Postpartum Depression", The Qualitative Report, cilt 10, say1 1, 2005, s. 23; K. D. Lynch, "Modeling Role Enactment: Linking Role Theory and Social Cognition", Journal for the Theory of Social Behaviour, cilt 37, say1 4, 2007, s. 380 . 
$\mathrm{Bu}$ çerçevede sembolik etkileşim kuramının kurucusu George Herbert Mead'in de önerdiği üzere roller sosyal etkileşim süreçlerince inşa edilirler. ${ }^{32}$ Mead'in roller konusundaki yaklaşımı sosyal yapılarla birlikte toplumların geçmiş tecrübelerini bir bütünlük içerisinde ele alırken; rollerin geleneksel yapısalcı yaklaşıma dayanan yorumlamaların açıklayamadığı niteliklerini de hesaba katar. Dolayısıyla onun rol yaklaşımı birey ile toplum arasındaki özgün bağı göz ardı eden salt deterministik anlayışla örtüşmeyen bir karakter arz eder. ${ }^{33}$ Rol icra eden bireylerin belirli bir sosyal kontekst içerisinde rollerini başkalarıyla olan etkileşimleri üzerinden şekillendirebilme yetisinde olduğunu varsayan sembolik etkileşim kuramının, ${ }^{34}$ rollerin icra süreçlerine önem atfettiği görülür. Belli bir sosyal kontekst içerisinde bireyden ortaya koyması beklenen davranış paternleri olan sosyal rollerle birlikte rollerin icra ediliş formları da toplumsal kültür tarafından üretilerek dil, atasözleri benzeri kültürel unsurlar yoluyla aktarılır. Aynı zamanda rol kodları aktörün rol icrasında neleri yapması gerektiğinin yanında, neleri yapmaması gerektiğini, rollerin icra edileceği mekân ve zamanı, rollerin ihlal edilmeleri durumunda aktörün maruz kalacağı sosyal yaptırımları da belirler. Rollerin icra ediliş formlanı, hiç şüphesiz aktörün de belli niteliklere sahip olmasını gerekli kılar. Öyle ki, rollerin kodları rol icra edecek aktörlerin kişilik özelliklerini, duygusal özelliklerini, giyim-kuşam tarzını, fiziksel niteliklerini de belirler.

Rolleri ve onlarla ilişkili davranış paternlerini sosyal kontekstler bağlamında üreten sosyal etkileşim süreçleri engelliliği ve engelli bireylerin konumlarını da inşa ederken; Charmaz, bu süreçlerin engelli bireyleri yok sayan veya indirgemeci yorumlamalarla damgalayan ve dışlanmalarına yol açan bir karaktere sahip olduğundan söz eder. Bedenlerin sosyal alanda var olurken bulundukları ortamlardaki varlıklarının anlamlarını, duyu hassalarının tetiklediği algılar, dil, ilişkiler ve etkileşimler eliyle kazandığına dikkat çeker (ki böylece engelli bedenler kusurlu/ayıplı olarak anlamlandırılmakla etiketlenmeye ve dışlanmaya maruz kalırlar.) Charmaz, sembolik etkileşim kuramının önde gelen yazarlarından E. Goffman'ın görüşlerine atfen, sosyal anlamlandırmaların engelli bireyleri farklılıkları sebebiyle damgalayarak ayrıştırırken onları "örselenmiş

32 V. Beneš - S. Harnisch, "Role theory in symbolic interactionism: Czech Republic, Germany and the EU", Cooperation and Conflict, cilt 50, say1 1, 2015, s. 149.

33 P. L. Callero - J. A. Howard - J A Piliavin, "Helping Behavior as Role Behavior: Disclosing Social Structure and History in the Analysis of Prosocial Action", Social Psychology Quarterly, cilt 50, say1 3, 1987, s. 248.

34 L. A. Zurcher, "Role Selection: The Influence of Internalized Vocabularies of Motive", Symbolic Interaction, cilt 2, say1 2, 1979, s. 46. 
kimlik"le yaşamaya zorladığını aktarır. ${ }^{35}$ Örselenmiş kimlikler aynı zamanda sosyal normallik kıstaslarından sapma durumudur ki değersizleştirici bir niteliğe sahiptir. O nedenle engelli bireylerin değersizleştirici anlamlar barınd1ran etiketlerle damgalanma süreçlerinde, fiziksel durumlarının görünür kıldığı farklılıklarına eşlik eden rol üstlenebilme ve rol icra edebilme konusunda yaşamaları muhtemel kısıtlılıklardan da söz etmek gerekir. Zira engelliliği görünür kılan fiziksel farkl11ıklar sosyal etkileşim süreçlerinde yetersizliğin ve acziyetin sembolleri halini alırken, rol üstlenme ve rol icra etme bakımından engellilik bir tür işe yaramazlık olarak algılanır.

Damgalanmış bir rol olarak engellilik bir sosyal sapma olarak görülebilse de toplumun meşruiyet sınırlarının dışında konumlandırılan bir sapma olarak görülmez. Çünkü engellilik rolüne yüklenen anlam ve engellilere yönelen sosyal reaksiyonlar sosyal değerlerin etkisiyle bir tür tolare edici bir mahiyette gerçekleşir. Engelliliğin bireysel bir iradeye dayanmıyor oluşu, tolare edilmesinin meşruiyetini kazandırır. Böylece engellilik engelli bireylerin üstlendiği diğer tüm rolleri domine eden temel (master) bir rol hüviyetine kavuşur. Engelli bireylerin engellerinden bağımsız olarak icra ettikleri diğer tüm rollerin yorumlanması, engellilik temel rolünün gölgesinde gerçekleşir. Engelli bir birey bir evlat değil engelli bir evlat, bir anne-baba değil engelli bir anne-baba, bir komşu değil engelli bir komşu, vatandaş değil engelli bir vatandaştır. Engelliliğin bireyin diğer tüm rollerini etkileme gücü, engelli bireyin dâhil olduğu sosyal etkileşimlerin ana zeminini ve muhatapları nazarındaki konumunu belirler. Dolayısıyla engelli bir bireyle olan etkileşimler onun üstlendiği diğer rolleri üzerinden değil, engelliliği üzerinden şekillenir. Engelli bir öğretmenin muhatap olduğu davranışlar bir öğretmene yöneltilmesi beklenen davranışlar olmaktan bir engelliye yöneltilmesi gereken davranışlara evrilir; öğretmenlik rolü engellilik rolünün gölgesinde anlamını yitirir. Engelli bireylerin toplumsal beklentileri karşılamayan yapıp etmeleri engelliliklerinin kaçınılmaz bir sonucu olarak görülen yetersizlikle gerekçelendirilirken; toplumsal beklentilere uygun veya bu beklentilerin fevkindeki davranışları çoğunlukla metafizik sebeplerle açıklanmaktadır. Meslekî rollerini engeli olmayan emsallerine göre daha başarılı bir şekilde yerine getiren bir engelli bireyin nisbî başarısının bir olağandışılık olarak algılanıp kendisine verilen metafizik yetenekleriyle gerekçelendirilmesi gibi.

35 K. Charmaz, "Experiencing Stigma and Exclusion: The İnfluence of Neoliberal Perspectives, Practices, and Policies on Living with Chronic IIllness and Disability", Symbolic Interaction, cilt 43, say1 1, 2020, s. 21-22. 
Diğer taraftan sembolik etkileşim kuramcılarının bazıları bakımından roller aynı zamanda birer kimlik olma vasfindayken ${ }^{36}$ etkileşim süreçleri kimlikleri de müzakereye açık hale getirir ${ }^{37}$. Bu noktadan bakıldığında rol üstlenme ve rol icra etme konusunda engellilik bir tür kimlik problemi hüvviyeti de kazanırken; rol icra etme kapasitesi bağlamında engelliliğe yüklenen anlamlar engelli bireylerin benliklerini yeniden üreterek onları gerçek benlikleriyle değil, bir "engelli ben" 38 ile yaşamaya sevk eder.

\section{c. Bilişsel Kuramlarda Rol}

Yukarıdaki paragraflarda değinildiği üzere hem yapısalcı-fonksiyonalist hem de sembolik etkileşim kuramları rol kavramını, bireyi sosyal güçlerin gölgesinde konumlandırarak açıklamayı önermektedirler. Yapısalc1-fonksiyonalist kuram 'bireyi rol ve yapıp etmeleri sosyal düzenlerin sıkı belirleyiciliği altında şekillenen bir aktör' olarak anlarken; sembolik etkileşim kuramı 'rollerin formasyon, üstlenilme ve icra süreçlerinin sosyal bağlamlar ve onları özgün kılan semboller eliyle belirlendiği' ni önermektedir. Gerçi sembolik etkileşim kuramı bireyin içinde bulunduğu sosyal ortamın uyaranlarını bir yoruma kavuşturup, bu uyaranların davranışlarına yön verme süreçlerini etkileşim kavramı üzerinden açıklayarak kognitif dinamiklerle sosyal yapılar arasında bir bağlantı tesis etmiştir. ${ }^{39}$ Ancak bu tespit, rol süreçlerinde bireyin makro ölçekli sosyal güçlerin belirleyiciliği altında olduğu varsayımını değiştirmemektedir. Bu noktada rollerin üstlenilme ve icra edilmelerinde bireyin zihinsel dinamiklerinin yerinin ne olduğu önemli bir soru olarak durmaktadır. Bu soruyu önceleyen rol tartışmaları, bu kavramı psikoloji disiplininin ilgi alanına taşımıştır. ${ }^{40}$

Rol kavramını bilişsel sosyal psikoloji perspektifi temelinde ele alan çalışmalara bakıldığında, bu kavramın rol ifa etme süreçleri, grup normlarının rol süreçlerine olan etkisi, rol üstlenme süreçleri gibi başl1klarda yoğunlaştı̆̆ görülmektedir. $\mathrm{Bu}$ çalışmalar genel olarak bu boyutların bireysel düzeydeki bi-

36 D. G. LoConto - D. L. Jones-Pruett, "Utilizing Symbolic Interactionism to Assist People with Mental Retardation during the Grieving Process. Illness", Crisis \& Loss, cilt 16, say1 1, 2008, s. 26.

37 A. Dietz-A. Thiessen-J. Griffith-A. Peterson-E. Sawyer-M. McKelvey, "The Renegotiation of Social Roles in Chronic Aphasia: Finding a Voice through AAC", Aphasiology, cilt 27, say1 3, 2013, s. 310; P. Tibbetts, "Symbolic İnteraction Theory and The Cognitively Disabled: A Neglected Dimension”, The American Sociologist, cilt 35, say1 4, 2004, s. 25.

38 Roe, Joseph ve Middleton, a.g.m. s. 35.

39 P. Collier - P. Callero, "Role Theory and Social Cognition: Learning to Think like a Recycler", Self and Identity, cilt 4, sayı 1, 2005, s. 45.

40 L. Clayton, "The Personality Theory of JL Moreno", Group Psychotherapy \& Psychodrama, say1 28, 1975, s. 144. 
lişsel süreçleriyle ilgilenmişlerdir. Örneğin Clayton, psikodramanın kurucusu olan Moreno'nun, rollerin üstlenilme ve icra edilme süreçlerinde bireyin içinde yaşadığı toplumsal arenadaki sosyal güçlerle birlikte bireyin özgün zihinsel dinamiklerinin etkinliğinin de belirleyici bir konumda olduğu önermesinde bulunduğunu bildirmektedir. ${ }^{41}$ Bireyin kimliği, içinde yaşadığ 1 toplumun kurumlarıyla birlikte kendi geçmiş yaşantı ve tecrübelerinin de şekillendiriciliği altında yapılanır. Dolayısıyla her bir rol sosyal güçler ile bireysel karakteristiklerin etkinliği altında tanım kazanır. Bu yönüyle roller sadece sosyolojik değil aynı zamanda psikolojik yönü olan olgulardır. ${ }^{42}$ Roller sosyal yapılarca aktörler için net sınırlarla tanımlanmış olsalar bile icra edilme süreçleri aktörün anlık tepkileriyle karakterizedir. Öyle ki, aktörlerin rollerini yerine getirmede ortaya koyacakları davranış formları da durum-spesifiktir (aynı roller farklı durumlarda farklı formlarla icra edilir). ${ }^{43}$ Rol ve beklenti arasındaki ilişkiye işaret eden bu yaklaşıma göre, birey bir aktör olarak üstlendiği rollerini icra etmede zihinsel olarak başkalarının algı ve beklentilerini dikkate almaya yönelir. Bu durum ise roller ve onların gerektirdiği davranış paternlerinin öğrenilmesinde bireyin sosyalizasyon süreçlerinin irdelenmesini önemli kılmaktadır. Zira sosyalizasyon, bireyin içinde yaşadığı kültürün kendisinden hangi davranışları beklediğini, kendisine yüklenen rollerin kodlarının neler olduğunu öğrenme sürecidir. ${ }^{44}$ Roller ve beklentilerin sosyalizasyon yoluyla öğrenilmesinde aile kurumu öncelikli bir yere sahiptir. Yetişkin bir birey olma yolunda ilerleyen çocuk için uygun olanı veya olmayanı öğrenmede anne-babası bir rol-model olma işlevi görür. Bu noktada engelli çocuklar aile içi iletişim yoluyla engelliliklerine ilişkin toplumsal beklentileri, engelliliklerine yüklenen anlamları büyük bir çoğunlukla engelli olmayan aile üyelerinden öğrenirler. Bir başka deyişle engelli çocukların sosyalizasyon süreçleri yoluyla engellilik öğretileri engellilik halini tecrübe etmeyen bireyler aracılığg ile gerçekleşir. Bu durumda engelliliğe karşı yerleşik toplumsal algılarla reaksiyon gösteren ebeveynler, değersizleştirici engellilik rollerinin engelli çocukların zihin dünyalarında yer edinmesinin de yolunu açar.

Özetle; roller, farklı kuramcılar tarafindan farklı boyutlarıyla ele alınmış ve farklı tanımlamalarla kavramlaştırılmış olsalar da bireylerin davranış formlarının, aktörler arasındaki ilişki örgülerinin, rollerle sosyal yapılar arasındaki ilişkilerin

41 Clayton, a.g.m. s. 144.

42 I. Z. Jakovina - T. Jakovina, "Role Theory and Role Analysis in Psychodrama: A Contribution to Sociology", Socijalna Ekologija, cilt 26, sayı 3, 2017, s. 151.

43 L. Yablonsky, “An Operational Theory of Roles”, Sociometry, cilt 16, say1 4, 1953, s. 351.

44 T. J. Blakely - G. M. Dziadosz, "Social Role Theory and Social Role Valorization for Care Management Practice”, Care Management Journals, cilt 16, say1 4, 2015, s. 184. 
açıklanmasında başvurulan temel kavramlardan birisi olmaya devam etmektedir. Yukarıda değinilen kuramsal yaklaşımlardan da anlaşılacağı üzere, roller etrafinda yaşanan tartışmalar genel itibarıyla bireyin davranışlarının şekillenmesinde sosyal yapıların belirleyiciliği ile bireyin davranış paternlerinin şekillenmesindeki kendi etkinliği (bireysel algılar, bireysel tercihler vb.) ikilemi üzerinden gerçekleşmektedir. Ancak Biddle ve Handel'ın da vurguladığı gibi, davranışların açıklanmasında aktör ve yapısal faktörler ikileminin etkinliğinin temel belirleyiciler olarak anlaş1lması, bütüncül bir rol kuramının yapılandırılması tartışmalarını da ortaya çıkarmıştır. ${ }^{45}$ Her ne kadar günümüz dünyasında iletişim imkânlarının ve kitle iletişim araçlarının sosyal kurumları sorgulanır hale getirmekte olduğu ve bireyin davranışlarının şekillenmesinde algı ve tercihlerin etkisinin ağırlık kazandığı gözlense de rollerin insan davranışlarının açıklanmasında başvurulan bir kavram olmaya devam edeceği düşünülebilir. Öte yandan toplumların iş ve üretim yönelimli bir nitelik kazanmaya devam etmeleri, rollerin bireyin toplumsal konum ve toplumsal değerini belirleme güçlerini arttırarak muhafaza edeceklerini akla getirmektedir. Dolayısıyla bir sonraki bölümde değinilecek olan SRV kuramının, Türkiye'de engellilere yönelik sosyal hizmet uygulamaları bakımından kuşatıcı ve bütüncül bir bakış açısı sağlayacağını söylemek yanlış olmayacaktır.

\section{Sosyal Rol Valörizasyon Kuramı ve Temel Önermeleri}

Bir önceki bölümde değinildiği üzere sosyal roller bireyin sosyal alandaki varlığı üzerinde belirgin bir etkiye sahiptir. Bireyin hem kendisi hem de başkaları hakkındaki algıları üstlenilen roller vasatında anlam kazanır. ${ }^{46}$ Roller ile bu rollere atfedilen toplumsal değer, toplumların ürettiği kaynak ve firsatların da yeniden dağıtılması süreçlerinin şekillenmesini etkiler. Dolayısıyla toplumların ürettiği firsat ve kaynaklar, sosyal olarak değerli sayılan rolleri üstlenme imkânlarına sahip bireyler için daha kolay erişilebilir durumdadır. Ama düşük statüde konumlandırılan ve değerli sayılan rolleri üstlenebilme kabiliyetinden mahrum oldukları varsayılan bireyler toplumsal firsat ve kaynaklardan faydalanamamakta ve sosyal dışlanmayla karşı karşıya kalmaktadırlar. ${ }^{47} \mathrm{Bu}$ durumda değerli sayılan sosyal roller üstlenebilmek, bir toplumda yüksek bir statüde konumlandırılmak ve toplumsal firsat ve kaynaklara erişebilmek noktasında belirleyici bir etken konumundadır. Bu gerçeklik aynı zamanda dezavantajlı olarak addedilen top-

45 Biddle, a.g.m. s. 76; Handel, a.g.m. s. 855.

46 W. Wolfensberger, “A Brief Overview of Social Role Valorization”, Mental Retardation, cilt 38, say1 2, 2000, s. 105.

47 R. Lemay, "Social Role Valorization Insights into the Social Integration Conundrum", Mental Retardation, cilt 44, say1 1, 2006, s. 1-2. 
lum kesimlerinin dezavantajlı hale gelmelerini de bir gerekçeye kavuştururken; Wolfensberger tarafından önerilen SRV kuramının ortaya koyduğu önermelerin temel isnat noktasını da oluşturmaktadır. ${ }^{48}$

SRV kuramı yaşlılık, engellilik, etnik köken gibi gerekçelerle sosyal değersizleştirilmeye muhatap olan ve değerli sayılan sosyal rolleri üstlenme imkânlarından mahrum bırakılmış bireylerin diğerlerine oranla firsat ve kaynaklara erişimlerinin kısıtlı olduğu varsayımı üzerine inşa edilmiş bir yaklaşımdır. ${ }^{49} \mathrm{O}$ halde sosyal değersizleştirilmeye muhatap olan bireyler, içinde yaşadıkları toplumlarca değerli sayılan rolleri üstlenebilme kapasiteleri geliştirildiği oranda değersizleştirmenin olumsuz etkilerinden uzaklaşırken; toplumsal firsat ve kaynaklara daha kolay erişebileceklerdir. ${ }^{50} \mathrm{Bu}$ çerçevede SRV Kuramının öncelikli hedefi, sosyal değersizleştirmeye maruz kalan toplum kesimlerinin üstlendikleri (değersizleştirilmelerine paralel olarak kendilerine atfedilen) sosyal rollerini iyileştirmek ve bireylerin rol üstlenme kapasitelerini geliştirmektir. ${ }^{51}$ Osburn, SRV kuramı terminolojisi bakımından toplumsal kaynak ve fırsatların işaret ettiği unsurların sadece maddi olanlarla sınırlı olmadığına dikkat çekmektedir. O, değerli sayılan rolleri üstlenmekten uzak olmanın hem bireyleri eğitim ve iş firsatları gibi maddi imkânlardan ve hem de haysiyet, kabullenilme, aidiyet hissi gibi bireyi saygın bir konuma taşıyan manevi unsurlardan yoksun bırakacağını dile getirmektedir. ${ }^{52}$ Yazarın bu tespitlerinin de işaret ettiği üzere SRV kuramı, değersizleştirici sıfatlarla etiketlenen toplum kesimlerinin muhatap oldukları değersizleştirilmenin yol açtığı psiko-sosyal problemlerin bertaraf edilmesine yönelmiştir. Bu çalışmanın savunduğu iddialar bakımından SRV kuramının iki boyutu önemli bulunmuştur:

48 W. Wolfensberger, "Social Role Valorization: A Proposed New Term for the Principle of Normalization", Mental Retardation, cilt 21, say1 6, 1983, s. 234.

49 Blakely - Dziadosz, a.g.m. s. 185.

50 Wolfensberger, a.g.m. s. 105.

51 W. Wolfensberger, "Social Role Valorization: A New İnsight, A New Term, for Normalization". Australian Association for the Mentally Retarded Journal, cilt 9, say1 1, 1985, s. 4; W. Wolfensberger, "Social Role Valorization and, or Versus, "Empowerment", Mental Retardation, cilt 40, say1 3, 2002, s. 252; W. Wolfensberger, "An "If This, Then That" Formulation of Decisions Related to Social Role Valorization As a Better Way of Interpreting It to People", Intellectual and Developmental Disabilities, cilt 49, say1 6, 2011A, s. 456; W. Wolfensberger, "Social Role Valorization and, or Versus, "Empowerment", Intellectual and Developmental Disabilities, cilt 49, say1 6, 2011B, s. 469; Wolfensberger, A Brief Overview of Social Role Valorization, s. 106.

52 J. Osburn, "An Overview of Social Role Valorization Theory", SRV/VRS: The International Social Role Valorization Journal/La Revue Internationale de la Valorisation des Roles Sociaux, cilt 3, say1 1, 1998, s. 7. 
Birincisi, SRV Kuramının önermeleri ve terminolojisinde merkezi konumda bulunan sosyal değersizleştirme kavramı; ikincisi kuramın ampirik bilgi ile pratik uygulamalar arasındaki ilişkiye sağladığı iç görüdür.

SRV kuramının önermelerinde sosyal değersizleştirme kavramı merkezi konumdadır. Toplumsal yaşamın akışı içerisinde bireyler diğerlerinin kendilerine yönelttiği değersizleştirici veya yüceltici tutumlara karşı bir duyarlılığa sahiptir; bu meyanda sosyal değersizleştirme, bireylerin hayatlarında uzun dönemli etkiye sahip bir realitedir. Ancak bireyi içinde yaşadığı toplumda değerli kılan statü ve roller kültürel değerler, toplumsal iş bölümü gibi spesifik unsurlara bağlı olarak değişkenlik gösterir. SRV kuramı söz konusu değersizleştirme ve bireylerin hayatlarına olan etkisi konusunda bir bilinç oluşturma iddiasındadır.

Cocks, sosyal değersizleştirme kavramın SRV kuramı perspektifinde ifade ettiği anahtar önemin anlaşılmasına 1şık tutan görüşler sunmaktadır. İnsanların algıları, (bilhassa ötekilere karşı gelişen algılar) muhataplarını bir tür değerlendirmeye tabi tutan bir karaktere sahiptir. Bu durum birtakım kişi veya kategorilerin değersiz addedilmesini kaçınılmaz kılar. Örneğin birçok toplumda engellilik, fakirlik, çeşitli etnik kategorilere ait olmak gibi bireyi çoğunluktan farklı k1lan özellikler ötekileştirilme ve değersizleştirilme gerekçelerine dönüşür. İnsanların muhataplarını bir değer skalasında konumlandıran algıları hem muhataplarıyla ilgili yaşanan geçmiş toplumsal tecrübelere hem de toplumsal inanç ve değerlere bağlı olarak şekillenir. Bir başka deyişle başkalarına değer takdir eden algıların hem toplumların sosyo-kültürel hafizalarıyla hem de inanç ve değerleriyle yakın ilişkisi vardır. O halde sosyal değersizleştirme süreçleri her toplumun kendi dinamikleri bağlamında açıklanabilen ve belli ölçülerde manipüle edilebilen bir olgudur..$^{53}$

SRV kuramının çalışma kapsamında önemli bulunan ikinci vasfı da ampirik bilgi ile pratik uygulamalar arasındaki ilişkiye verdiği önemdir. Nitekim Wolfensberger, SRV yaklaşımını genel hatlarıyla "ampirik bilginin bireyler ile grup sinıf gibi bazı kategorik aktörlerin halihazırdaki ya da potansiyel sosyal rollerinin yeniden tanımlanmast yolunda kullanılması" 54 olarak tanımlamaktadır. Ona göre aktörlerin rollerinin yeniden tanımlanması, yetenek ve imajlarının diğerlerinin gözünde olabildiğince değerli addedilmesi sonucunu doğuracaktır. ${ }^{55}$ Toplumların rollerin icra süreçlerini denetleyen normatif mekanizmaları her top-

53 E. Cocks, "Normalisation and Social Role Valorisation: Guidance for Human Service Development", Hong Kong Journal of Psychiatry, cilt 11, say1 1, 2001, s. 13.

54 Wolfensberger, "Social Role Valorization: A New İnsight, A New Term, for Normalization”, s. 5.

55 Osburn, a.g.m. s. 7. 
lum için özgün bir karaktere sahiptir. Aynı şekilde rollere atfedilen toplumsal değerler de toplum-spesifik bir karakter gösterir. Her rol her toplum için aynı derecede değerli sayılmayabilirken, rolleri üstlenen bireylerin toplumsal konumları da her toplum için değişkenlik gösterir. Bu bağlamda SRV kuramının her toplum için genelgeçer ve katı sınırlarla belirlenmiş uygulama önerileri öne sürmediğini belirtmek gerekir. ${ }^{56} \mathrm{SRV}$ her toplumun insan davranış ve etkileşim süreçlerini bir düzene kavuşturan spesifik kodlarının olduğunu kabul ederken, değerli sayılan rolleri icra etme kapasitesinin her toplum bakımından farklı dinamikler eliyle kazandırılabileceğini önermektedir. Dolayısıyla SRV kuramının çizdiği genel perspektif bilimsel yöntemlerle elde edilen ve değerlendirilebilen realiteler bağlamında toplum-spesifik uygulama örneklerinin hayata geçirilmesini öncelemektedir. Yaşl1lar, engelliler gibi dezavantajlı gruplara yönelik uygulamaların geliştirilmesine fikrî bir zemin oluşturma iddiasıyla önerilen SRV kuramının, sosyal değersizleştirmeye muhatap olan kategorilerin başında gelen engellilerin fiziksel, psikolojik, sosyal uyumu entegrasyonları ile iyilik hallerinin geliştirilmesi alanlarında çeşitli pratik uygulamalara ilham kaynağı olduğu görülür. ${ }^{57}$

Cocks, SRV kuramını kuramsal ve felsefi bir yaklaşım olarak değerlendirir. Fakat ampirik bilgi ile pratik uygulamalar arasında bir ilişki oluşturma iddiasının somut sonuçlarının, öğrenme güçlüğü çeken ve psikiyatrik sorunları olan bireyler ile yaşlılara yönelik hizmetlerde gözlendiğine de dikkat çekmektedir. Zira kuramın önermeleri Amerika Birleşik Devletleri, Kanada, İskandinavya, Birleşik Krallık, Avustralya ve Yeni Zelanda gibi ülkelerde dezavantajlı kesimlere sağlanan kurumsal hizmetlerin reforma tabi tutulmasına ilham kaynağı olmuştur. ${ }^{58}$ Diğer taraftan SRV kuramı katı sınırlarla çerçevelenmiş bir uygulama şablonu önermekten ziyade, uygulamacılara hizmet sağladıkları kitlelerin içinde yaşadıkları sosyal ortamlarca değerli sayılan rolleri üstlenip icra etme kapasitesi kazandırılması noktasında bir tür iç görü önermesinde bulunur. ${ }^{59}$ SRV kuramının kendi önermelerinin uygulama planında karşılık bulması noktasında toplumların özgün karakterlerine yaptığı vurgu, sosyal hizmet uygulayıcılarının kendi lokal

56 Wolfensberger, "Social Role Valorization and, or Versus, "Empowerment"”, s. 470.

57 T. Aubry - R. J. Flynn - B. Virley - J. Neri, "Social Role Valorization in Community Mental Health Housing: Does It Contribute To the Community Integration and Life Satisfaction of People With Psychiatric Disabilities?", Journal of Community Psychology, cilt 41, say1 2, 2013, s. 219; R. J. Flynn - N. LaPointe - W. Wolfensberger - S. Thomas, "Quality of İnstitutional and Community Human Service Programs in Canada and the United States", Journal of Psychiatry and Neuroscience, cilt 16, say1 3, 1991, s. 146.

58 Cocks, a.g.m. s. 12.

59 Lemay, a.g.m. s. 1. 
sosyo-kültürel şartları dahilinde ve SRV bakış açısıyla özgün pratikler geliştirebilme şanslarını arttırmaktadır. Çalışmanın sonraki bölümünde değinildiği üzere Türk toplumunun sosyo-kültürel hafızası SRV kuramının temel önermeleri perspektifinde engellileri sosyal değersizleştirme riskinden koruyan uygulamalar geliştirilmesi için uygun bir zemin sağlama potansiyelindedir.

\section{Osmanlıda İşitme Engellilerin Devlet Kurumlarında ve Görme Engellilerin Hafızlık Müessesesinde İstihdamları}

Daha önce de belirtildiği üzere, bu çalışmanın temel iddiası Türk toplumunun engelli bireylerin değerli roller üstlenmelerine imkân veren bir sosyo-kültürel geçmişe sahip olduğudur. Çalışmanın bu bölümünde bu iddia, engelli bireylerin değerli roller üstlenmelerini mümkün kılan bazı geçmiş dönem uygulamaları aracılığı ile irdelenecektir. Bu çerçevede Osmanlı döneminde işitme engellilerin çeşitli devlet kurumlarında üstlendikleri görevler ile görme engellilerin din hizmetlerinde ve hafizlık müessesesinde istihdam edilmeleri ele alınacaktır. Keza bu çalışma Osmanlı Devleti döneminde engellilerin durumlarını ele almayı önceleyen bir çalışma değildir; bu itibarla yukarıda belirtilen kendi iddiasını ortaya koyabilmek bakımından ilerleyen paragraflarda değinilen örnek uygulamaların yeterli olacağ değerlendirilmiştir.

Her şeyden önce belirtmek gerekir ki, engelliler Osmanlı toplumunda birçok toplumda görüldüğü şekliyle sosyal ayrıştırmaya tabi tutulmamışlardır; Sağlam-Tekir ile Şimşek tarafından da belirtildiği üzere toplumla iç içe yaşamışlardır. ${ }^{60}$ Hatta etrafındakilere rahatsızlık verici davranışlar göstermeyen akıl hastaları dahi tedavi amaçlı bile olsa şifahane adı verilen kurumlarda uzun süreli tutularak toplumdan tecrit edilmemişlerdir. ${ }^{61}$

\section{a. Osmanlıda İşitme Engellilerin Devlet Kurumlarında İstihdamları}

Osmanlı toplumunda engellilik meselesini ele alan birçok çalışma, ${ }^{62}$ devlet kurumlarında üstlendikleri kritik görevler itibarıyla işitme engellilere ve işaret

60 H. Sağlam - Tekir, “Toplumsal Hayatta Karşılaştıkları Zorluklarla Osmanlı Devletinde Sağır, Dilsiz ve Âmâlar”, Osmanlı Mirası Araştırmaları Dergisi (OMAD), cilt 3, sayı 7, 2016, s. 60; K. Şimşek, "Osmanlı Devletinde Engelliler İçin Kullanılan Tabir, Lakap ve Sıfatlar", Belgi Dergisi, cilt 2, say1 15, 2018, s. 729.

61 Şimşek, a.g.m., s. 732.

62 Bknz: (Örneğin), S. Balc1, Osmanlı Devleti’nde Engelliler ve Engelli Eğitimi Dilsiz ve Ama Mektebi, İstanbul, Libra Yayınları, 2013. Birçok çalışma denilmesine rağmen sadece bir örnek verilmiş. Bu alanda konuya zenginlik kazandırılması amacıyla 2020 yılında İstanbul Üniversitesi Yayınevi tarafından basılmış olan "Engellilik Tarihi Yazıları" başlıklı kitabın içerisinde yer alan çalışmalara bakılabilir. 
dilinin kullanımının yaygınlığına bilhassa değinmişlerdir. İşitme engellilerin Osmanlı sarayındaki konumları ve üstlendikleri görevler yabancı ziyaretçilerin de hayranlık ve ilgisine mazhar olmuş, ${ }^{63}$ bu ziyaretçilerin seyahatname ve hat1ralarında yazdıkları, Osmanlı'da işitme engellilerin durumları ile işaret dilinin kullanımına ilişkin yapılan akademik çalışmaların atıfta bulunduğu başlıca kaynaklardan olmuştur.

Osmanlı'da işitme engellilerin (çoğunlukla dilsiz anlamına gelen "bizeban" ifadesiyle de anılırlardı) çeşitli devlet kurumlarında, ağırlıklı olarak da sarayın Harem ve Hırka-i Saadet gibi çeşitli bölümleri ile mahkemelerde istihdam edildikleri görülür. Çeşitli askerî ve sivil kurullarda istihdam edildikleri, askerî törenler ile padişah kabullerinde yer aldıkları, saraya alınan eşyaların getirilmesinde, bazı devlet görevlilerinin muhallefâtının sayımında görevlendirildikleri de yazılmıştır. ${ }^{64}$ Hiç şüphe yok ki, işitme engellilerin Osmanlı sarayında üstlendikleri en değerli rol musahiplik rolüydü. ${ }^{65}$

Musahiplik rolünün değerini kelimenin ifade ettiği anlam ile bu rolü üstlenenlerin görevleri üzerinden anlamak mümkündür. İpşirli tarafından belirtildiğine göre musahip kelimesi sözlükte "sohbet ehli kimse, arkadaş, dost" anlamlarına gelirken; Osmanlı sarayında padişahın yanında bulunan ve ona bir nevi danışmanlık yapan görevlilere musahip denirdi. ${ }^{66}$ Musahiplik rolünün tanımından da anlaşılacağı üzere, bu rolü üstlenenlerin padişahlara danışmanlık hizmeti verebilmeleri için belli konularda bilgi birikimine sahip ve iyi eğitim almış kişiler olmaları gerekir. Diğer taraftan Osmanlı padişahlarının şehzadelik dönemlerinden başlayarak tahta hazırlanmaları adına tâbî tutuldukları eğitim dikkate alındığında, işitme engellilerin bilgi birikimi son derece güçlü olan padişahlara danışmanlık hizmeti verme durumunda oldukları kolaylıkla anlaşılacaktır. Bu cümleden olarak musahiplik rolünün önemli ve nitelik gerektiren bir rol olmasının yanında

63 Balc1, a.g.e., s. 48; K. Richardson, "New Evidence for Early Modern Ottoman Arabic and Turkish Sign Systems", Sign Language Studies, cilt 17, say1 2, 2017, s. 173; S. Scalenghe, Disability in the Ottoman Arab World, 1500-1800 (Cambridge Studies in Islamic Civilization), Cambridge, Cambridge University Press, 2014, s. 21.

64 Balcı, a.g.e., s. 48; 52-53. (Sezai Balcı'nın çalışması kitap olduğu halde adı geçen makale şeklinde kısaltılmıştır)

65 N. Günay, “Osmanlı Devleti'nde Engellilerin İstihdamı ve Saray Teşkilatında Dilsizler”, Uluslararası Kültürel ve Sosyal Araştırmalar Dergisi (UKSAD), cilt 2, sayı 1, 2016, s. 66; M. İpşirli, "Musahiblik", TDV İslâm Ansiklopedisi, cilt 31, İstanbul, TDV Yayınları, 2006, s. 231; M. Miles, "Signing in the Seraglio: Mutes, Dwarfs and Jestures at the Ottoman Court 15001700", Disability \& Society, cilt 15, say1 1, 2000, s. 120.

66 İpşirli, a.g.m., s. 230. 
son derece muteber bir rol olduğu ortaya çıkmaktadır. Nitekim Günay, padişaha musahiplik yapan işitme engellilerin sarayda itibar gören kimseler olmakla maiyetlerine verilmiş görevlilerin olduğunu yazmaktadır. ${ }^{67}$

İşitme engellilerin devlet kurumlarında istihdam edilmesi uygulamasının I. Beyazıt dönemine kadar uzandığını söyleyen tarihçiler olmakla birlikte ${ }^{68}$; Fatih Sultan Mehmet döneminde yaygın bir uygulamaya dönüştügü bilinmektedir. ${ }^{69}$ Kemaloğlu ve Yaprak-Kemaloğlu, işitme engellilerin sarayda ve devlet dairelerinde gizliliği temin eden personel olarak güvenlik hizmetleri, haberleşme hizmetleri gibi pozisyonlarda istihdam edildiğini bildirdikten sonra işitme engellilerin sarayda istihdam edilmelerinin devlet hizmetleri bakımından iki fonksiyonuna işaret etmektedirler. İlk olarak işitme engellilerin devlet hizmetinde istihdam edilmeleri yoluyla devlet sırlarının ifşâ edilmesi ihtimali azaltılırdı. İkincisi ise işitme engelli görevliler saray ziyaretçilerinin kendi aralarındaki konuşmaların dudak okuma yoluyla deşifre edilmeleri konusunda yararlılıklar gösterirler; bir tür istihbarî görev üstlenirlerdi. ${ }^{70}$

Hiç şüphe yok ki, Osmanlı sarayında mahremiyetin korunduğu kritik alanlardan birisi de harem dairesiydi. Dolayısıyla harem dairesi işitme engellilerin sarayda ağırlıklı olarak istihdam edildiği bir başka kısım olma konumundadır ki sadece işitme engelli erkeklerin değil, işitme engelli kadınların da sarayda aktif olduklarını gösteren delillerin varlığından söz etmek gerekir. ${ }^{71}$ İlgili literatüre bakıldığında, aslında Osmanlı döneminde işâret dilinin yaygınlığının ve işitme engellilerin devlet kurumlarında istihdamlarının tek sebebinin gizliliğin ve mahremiyetin korunması kaygılarından ibaret olmadığı görülür. Örneğin Miles, Osmanlı'da sadece mahremiyetin değil, aynı zamanda sessizliğin ve sükûnetin ihtiyaç duyulduğu her yerde işâret dilinin tercih sebebi olduğuna dikkat çekmektedir. ${ }^{72}$ Diğer taraftan Kemaloğlu ve Yaprak-Kemaloğlu'na göre Osmanlı'da işaret dili "sessizliğin dili" olarak adlandırılırken, işaret dilinin öğrenilmesi de "sessizliğin güzelliğinin öğ-

67 Günay, a.g.m., s. 67.

68 Miles, a.g.m., s. 117.

69 M. Miles, "Deaf People, Sign Language \& Communication, In Ottoman \& Modern Turkey: Observations and Excerpts from 1300 to 2009. From sources in English, French, German, Greek, Italian, Latin and Turkish, with İntroduction and Some Annotation", Independent Living Institute, 2009, https://www.independentliving.org/miles200907.html, (Erişim Tarihi: 11/02/2021); Richardson, a.g.m., s. 177.

70 Y. Kemaloğlu - P. Yaprak-Kemaloğlu, "The History of Sign Language and Deaf Education in Turkey”, Kulak Burun Boğaz Ihtisas Dergisi, cilt 22, say1 2, 2012, s. 69.

71 Miles, a.g.m., s. 117.

72 Miles, a.g.m., s. 116. 
renilmesi" olarak tasvir edilmiştir. ${ }^{73}$ Dolayısıyla söylenebilir ki, işitme engelliler sessiz iletişimin tercih edildiği her ortamda avantajlı bir konumda olmuşlar; bu konumları onlara değerli roller üstlenme firsatı sağlamıştır.

İşitme engellilerin istihdam edildikleri bir başka devlet kurumu da mahkemelerdi. ${ }^{74}$ Osmanlı mahkemeleri padişahların sükûnete özel önem verdikleri bir aland, bu durum işaret dilinin mahkeme hizmetlerinde kullanımını teşvik eden bir husus olmuştur. ${ }^{75}$ İşitme engellilere kadılık görevi verilmemekle birlikte, mahkeme işlerinin yürütülmesinde ihtiyaç duyulan çeşitli memurluk pozisyonlarında çalışmaktaydılar. Bu noktada şu hususu da belirtmek gerekir ki, işitme engellilerin Osmanlı mahkemelerinde istihdam edilmeleri bir koruma değil, engellerinin bir avantaj olarak görülmesi anlayışına dayanıyordu. İşitme engellilerin mahkemelerde istihdam edilmeleri başkentle sınırlı değildi, bu uygulama devletin farklı bölgelerinde de hayata geçirilmişti.

Miles, işitme engellilerin devletin farklı bölgelerinde devlet kurumlarında istihdam edildiğini, hatta işaret dilinin kullanımının sadece saray ve devlet daireleriyle sınırlı olmadığını, taşrada yaşayan işitme engellilerin de bu dili bildiklerini ve etkin olarak kullandıklarını söylemektedir. ${ }^{76}$ Richardson de bu görüşleri destekler mahiyette bilgiler aktarmaktadır: Osmanlı'da İstanbul dışında Halep'te de işaret dili alfabesinin Arapça bir varyantının 1589 yahut 1590 yılında kısmî ölçüde kayıtlara geçtiği bilinmektedir. ${ }^{77} \mathrm{Bu}$ bilgiler, işaret dilinin kullanımının merkezî devlet birimleriyle sınırlı olmadığını göstermesinin yanında, Osmanlı'da engellilik olgusuna verilen toplumsal reaksiyonların engelli bireyleri değersizleştiren bir karaktere sahip olmadığını göstermektedir. Nitekim Richardson, Alman seyyah Johannes Leunclavius'un İstanbul ahalisinden görüştüğü kimselerin kendisine "sultanın dilsizleri gönlü işaret ile açarlar ve işaretle mütekabilen anlatırlar ve anlarlar." dediklerini nakletmektedir. ${ }^{78}$

İşaret dilinin saray ve yargı hizmetleri gibi çok önemli alanlarda kullanımda olması, bu dilin bir taraftan zengin bir kelime haznesine sahip olduğunu, diğer taraftan da işitme engeli olmayanlarca da bilindiğini ortaya koymaktadır. İşaret dilinin padişahlar ve diğer saray görevlileri tarafından da etkin olarak

73 Y. Kemaloğlu - P. Yaprak-Kemaloğlu, a.g.m., s. 69.

74 Y. Kemaloğlu - P. Yaprak-Kemaloğlu, a.g.m., s. 69; Miles, a.g.m., s. 115; Scalenghe, a.g.e., s. 21-22.

75 Richardson, a.g.m., s. 176.

76 Miles, a.g.m., s. 4.

77 Richardson, a.g.m., s. 173.

78 Richardson, a.g.m., s. 176. 
kullanıldığına dikkat çeken Miles, işaret dilinin işitme engeli olmayan kişiler tarafından öğrenilmesinde bu dilin kullanımının pratikliğinin de belirleyici bir etken olduğunu iddia etmektedir. Yine memuriyetten emekli olmuş işitme engellilerin, işaret dilini, devlet hizmetlerinde çalışmaya başlayan daha genç işitme engelliler ile işitme engelli olmayanlara öğretmek üzere görevlendirilmeye devam edildiklerini, Topkapı Sarayı bünyesinde işaret dili eğitimi verilen bir bölümün de bulunduğunu belirtmektedir. ${ }^{79}$

Osmanlı devleti çöküş ve yıkılma sürecini yaşadığ 1 dönemlerde de engellilerin eğitimlerine önem verme anlayışını terk etmemiştir. II. Abdülhamit döneminde başkent İstanbul'da işitme, konuşma ve görme engelliler için bir okul açılmıştır. ${ }^{80} \mathrm{Bu}$ okulun açılması için Maarif Nezareti'ne bir layiha sunan Ferdinand Grati'nin Ticaret Mektebi'nde görevli olması nedeniyle engelli okulu bu mektebin bünyesinde kurulmuştur. ${ }^{81}$

\section{b. Osmanlıda Görme Engellilerin Hafızlık Müiessesesinde İstihdamları}

Osmanlı toplumunda görme engelliler de (âmâlar) sosyal hayatın tam olarak içinde yer almışlar ve farklı alanlarda değerli addedilen roller üstlenmek suretiyle görünür olmuşlardır. Bu roller arasında müzisyenlik ve hafızlık rollerinin âmâlar tarafından ağırlıklı olarak üstlenilen roller olduğu anlaşılmaktadır. Bu çalışma, kendi iddiaları bakımından en muteber rollerden olan hafızlık rolüyle görme engellilerin din hizmetlerinde istihdamlarına değinmekle yetinecektir. Osmanlı toplumunda görme engellilerin üstlendikleri hafızlık rolü, onları sosyal değersizleştirme süreçlerinden koruma ve daha da önemlisi itibar kazandırma gücüne sahipti. Bu gücü daha iyi anlatabilmek adına öncelikle Osmanlı toplumunda hafızlık rolünün ve din eğitiminin yerine değinmek gerekmektedir.

Hafızlık müessesesi sahabe döneminden itibaren önemsenmiş ve değerli addedilmiş; bu önem çağlar boyunca tüm İslâm toplumlarında devam etmiştir. Kur'ân'ın ezberlenmesine verilen önem bir ölçüde ilk dönemlerde yazı ve matbuat imkânlarının sınırlılığına bağlı olarak korunup sonraki nesillere aktarılma kaygısıyla açıklanabilir bir durum olmakla birlikte, hafızlığı değerli bir rol konumuna yükselten asıl dinamik bu rolün ibadet boyutudur. ${ }^{82}$ Osmanlı'da Kur'an

79 Miles, a.g.m., s. 4.

80 Y. Tanyeri, “İzmir School for the Deaf”, Turkish Archives of Otorhinolaryngology, cilt 54, say1 1, 2016, s. 1.

81 Kamuran Şimşek, "II. Abdülhamit Dönemi Osmanlı Devleti'nde Engelliler ve Engelli Politikaları (1876 - 1909)", (Yayımlanmamış Doktora Tezi), Pamukkale Üniversitesi Sosyal Bilimler Enstitüsü, Denizli, 2017, s. 194-196.

82 H. Ş. Aynur, "Başlangıcından Günümüze Kadar İslam Coğrafyasında Hafızlık Tedrisatı", Dinbilimleri Akademik Araştırma Dergisi, cilt 11, say1 2, 2011, s. 199. 
eğitiminin genel eğitim sistemi içerisinde ağırlıklı bir yere sahip olduğu bilinmektedir. Kur'an eğitimleri Dar-ul-Kur'ân, Dar-ul-Huffaz ve Dar-ul-Kurra adı verilen eğitim kurumlarında verilirdi. ${ }^{83}$

Bu noktada belirtmek gerekir ki, Osmanlılar Kur'an eğitimi veren kurumları büyük ölçüde kendilerinden önce aynı topraklarda hüküm süren ve devamı oldukları Selçuklulardan tevarüs etmişlerdir. ${ }^{84}$ Osmanlılar Selçuklulardan devraldıkları Kur'an eğitimi veren kurumları sınırlarına kattıkları topraklarda sayıca çoğaltagelmişlerdir. ${ }^{85}$ Başta padişahlar olmak üzere devlet büyüklerinin adlarına yapılan her caminin yanında bir de Kur'ân eğitim merkezinin de bulunmas ${ }^{86}$ göstermektedir ki, hafızlık müessesesine, bu kurumların faaliyetlerine, Kur>ân eğitimine ve bu eğitimi alan öğrencilere özel bir önem atfedilmiştir. Osmanlı dışındaki beldelerde yaşayan devrinin bazı ünlü hafızlarının Osmanlı ülkesine göç etmesi; ${ }^{87}$ bu kurumlarda eğitim alan ve başarılarıyla temayüz eden öğrencilere özel törenlerde sertifikalar verilmesi ve taltif edilmesi; Osmanlıdaki vakıf kültürünün bir gereği olarak Kur'ân eğitimi veren kurumların güçlü vakıflarla korunması verilen önemi göstermektedir. Örneğin Kur'ân eğitimi veren kurumların vakıflarına ait çeşitli vakfiyelerde, ilgili eğitim kurumunda eğitim alacak öğrencilerin sayılarının sınırlandırıldığı görülür. Bu tür bir s1nırlandırma eğitmenlerin daha az sayıdaki öğrenciyle daha ihtimamlı ilgilenebilmelerini sağlayarak eğitimin niteliğini yükseltmeye yönelik bir tedbirdir. ${ }^{88}$ Kur'ân eğitimi veren kurumların varlıklarının ve hizmetlerinin devamlılığ ile öğrenciler ve eğitim görevlilerinin başta maişet olmak üzere her türlü ihtiyaçlarının da en ince ayrıntısına kadar düşünülmüş olduğu da yine vakfiye kayıtlarından anlaşılmaktadır. ${ }^{89}$

Osmanlılarda Kur'ân eğitimine ve hafızlığa verilen önem çerçevesinde yukarıda öz olarak değinilen hususlar hafızlık rolünün sadece formal düzeyde de-

83 Aynur, a.g.m., s. 207; S. Bhutto, "Traditional and Modern Methods Used for Memorization of Quran in Turkey”, Ma'arif Research Journal, say1 10, 2015, s. 91-92; A. Gökdemir, “Osmanl1 Kur'ân Eğitim Merkezleri: Dârulkurrâlar ve Sibyan Mektepleri”, Edebali İslamiyat Dergisi, cilt 1, say1 2, 2017, s. 44.

84 Bhutto, a.g.m., s. 91.

85 Aynur, a.g.m., s. 208; D. Nureski, “Osmanlı'dan Günümüze Makedonya'daki Türk Kültürü ve Makedonya’nın Türk Kültür Tarihindeki Yeri ve Önemi”, Avrasya Etudleri, sayı 50, 2016, s. 368.

86 Y. Kurt, “Kur'ân'ın Korunmasında Hâfızlık Müessesesi”, Hitit Üniversitesi İlahiyat Fakültesi Dergisi, cilt 11, say1 22, 2012, s. 245.

87 Bhutto, a.g.m., s. 92.

88 Aynur, a.g.m., s. 209.

89 Gökdemir, a.g.m., s. 46. 
ğil toplumsal ölçekte de son derece değerli addedildiğini göstermektedir. Zira Kur'ân ve hafizlık eğitimi veren kurumların varlıklarının sürdürülebilirliğini muhafaza eden ve yukarıda kısaca sözü edilen vakıflar, hayır sahibi gerçek kişiler tarafindan kurulmuşlardır. Tüm Kur'ân'ın İslâm toplumları için sosyal ve kültürel hayatın merkezinde konumlanma durumu ${ }^{90}$ Osmanlılar için de geçerlidir. Osmanlı toplumunda görme engellilerin müezzinlik, kurralık ve hafızlık rollerini üstlenmeleri teşvik edilmiştir ${ }^{91}$ Halk arasında görme engellilerin bilhassa ileri yaştaki kimselerce "Hafız" namıyla çağırılmalarının Osmanlı döneminden tevarüs eden bu önemle ilişkili olduğunu düşünmek pekâlâ mümkündür. Balc1, görme engellilerin Hafızlık rolü üstlenmeleri bahsinde Cami-i Ezher'de bulunan Zâviyetü'l Umyân Medresesinde eğitim gören öğrenciler arasında görme engellilerin de varlığından söz etmektedir. ${ }^{92}$ Dalyan ve Ünisen ${ }^{93}$ ise Sıhhat ve İçtimai Muavenet Vekâleti (Sağlık ve Sosyal Yardım Bakanlığı) kayıtlarında görme engellilere hafızlık eğitimi vermek üzere bir Dar-ul-Huffaz kurumunun var olduğunu yazmaktadir.

Görme engellilerin din hizmetlerinde istihdam edilmeleri ve hafizlık eğitimi almaları konusundaki hassasiyetin sonraki yıllarda da devam ettiği yahut bir tür kültüre dönüştüğü görülmektedir. Örneğin bir göz doktoru olan Mehmet Esat, Belçika'da düzenlenen körler kongresine katılmış, dönüşünde kendisine bu kongreye katılma görevi veren Sultan II. Abdülhamid'e bir rapor sunmuştur. Raporunda Dar'ül Aceze bünyesinde bir körler okulu kurulmasını, okulda okutulacak çeşitli derslere ilâveten Müslüman öğrencilere Kur'ân ve hafizlık eğitimi de verilmesini tavsiye etmiştir. ${ }^{94}$ Dalyan ve Ünisen, Adıyaman özelinde yaptıkları çalışmalarında Trahoma hastalığı sebebiyle bölgede yaşayan görme engellilerin sayılarının artması karşısında bu kişilere Hafızlık eğitimi verilmesi yoluna gidildiğini belirtirlerken, bu uygulamanın bir devlet politikası olmadığının ve halk tarafından geliştirilen enformal bir çözüm yolu olduğunun da altını çizmektedirler. ${ }^{95}$

Yazarların Cumhuriyetin ilk yıllarında yaşanan bu gelişmenin görme engelli bireylere hafızlık rolü üzerinden sosyal itibar kazandırmak gibi bir amacının olduğunu belirtmiş olmaları, bu çalışmanın iddiaları bakımından önemlidir. Söz

90 Scalenghe, a.g.e., s. 79.

91 Balc1, a.g.e., s. 38; Scalenghe, a.g.e., s. 79-80.

92 Balc1, a.g.e., s. 38.

93 M. G. Dalyan - A. Ünisen, "Engelli Eğitimine Alternatif Bir Bakış: Hafızlık Eğitimiyle Görme Engellilere Toplumsal Saygınlık Kazandırılması (Osmanlıdan Cumhuriyete Adıyaman'da Kör Hafizlar)", Route Education and Social Science Journal, say1 12, 2016, s. 2-3.

94 Balc1, a.g.e., 148; Dalyan - Ünisen, a.g.m. s. 2.

95 Dalyan - Ünisen, a.g.m., s. 2. 
konusu çalışmada yer verilen bu görüşler, görme engelli hafızların eğitimlerini tamamladıktan sonra yörede gerçekleştirilen dinî tören ve sohbetlere etkin birer katılımcı sıfatıyla dâhil olduklarının ve halktan büyük itibar gördüklerinin belirtilmesiyle desteklenmiştir. Scalenghe, görme engellilerin Kur'ân ezberleyerek din hizmetlerinde istihdamlarıyla ilgili olarak görüşlerini belirtmektedir. Verdiği bilgiler, Osmanlı toplumunda var olan ve günümüze intikal eden sosyo-kültürel zeminin aslında görme engellilerin değerli roller üstlenebilmelerine sağladığ 1 imkânlarla birlikte engellilik olgusuna karşın gelişen toplumsal reaksiyonları şekillendiren temel dinamikler hakkında da önemli ipuçları barındırmaktadır. Şöyle ki;

İslâm hukukunda görme engellilerin hayatlarını kazanmaları adına çalışmalarına mâni bir hüküm bulunmazken, birçok görme engelli de çeşitli işlerde çalışmıştır. Bu çerçevede Osmanlı döneminde müezzinlik, Kur`ân öğreticiliği, kurralık görme engellilerin yaygın olarak icra ettikleri mesleklerdi. Profesyonel kurralara duyulan ihtiyaç dolayısıyla kurralık diğer mesleklere oranla daha kazançlıydı. Kurralar sadece camilerde görev yapmazlardı, cenaze ve özel günlerde de hizmet görürlerdi, bu arada evlerde de Kur`ân okurlardı. Evlere kurra davet edilmesi söz konusu olduğunda görme engelli kurralar gören emsallerine oranla daha fazla tercih edilirdi; çünkü görme engelli bir kurranın evin mahremiyetini gözleriyle ihlal etme imkânı yoktu. Yazar görme engellilerin Kur`ân ezberleyerek kurralık yapmalarının görme engelliliği diğer engel türleri arasında öne çıkaran bir husus olduğuna değinirken, görme engellilerin kurralık yapma konusunda sahip oldukları fitrî bir avantaja da dikkat çekmektedir. Esas itibarıyla bilginin özellikle geçmiş dönemlerde sözel yollarla transferi görme engellilere bir avantaj sağlamaktadır. Ancak Kurıân ezberlemek ve profesyonelce okumak söz konusu olduğunda bu işitme kabiliyetinin gelişmiş olması ilave bir avantajı daha beraberinde getirmektedir. Çünkü Kurıân`ın profesyonel bir şekilde okunabilmesi tecvid kurallarının doğru bir şekilde uygulanabilmesiyle mümkünken; tecvid kurallarına bağlı telaffuz formlarının ve harflerin mahreçlerinin yazılı sembollerle ifade edilebilmesi tam olarak mümkün değildir. Bir başka deyişle tecvit kurallarına uygun kıraat duyularak öğrenilebilir; Kur>ân okumanın öğrenilmesi doğru telaffuz formlarının ancak duyularak öğrenilmesiyle mümkün olabilir. ${ }^{96}$

Scalenghe, yukarıdaki tespitleri çerçevesinde görme engellilerin kurralık üzerinden değerli rol üstlenebilme kabiliyetleriyle ilişkili iki önemli sosyokültürel hususa göndermede bulunmaktadır. Birincisi Kur'ân öğrenmek ve profesyonel bir şekilde okumak görme yetisinden ziyade gelişmiş bir duyma yetisi gerektir- 
mektedir ki Kur'ân'ın okunması kültürü, duyma yetisi güçlü bireylere bir avantaj sağlamaktadır. İkincisi de Müslüman Osmanlı toplumunda mahremiyetin korunması son derece önemlidir. Bu iki nokta aslında görme engelliliği bireye getirdiği çeşitli kısıtlılıkların yanında bir tür avantaja dönüştürmektedir. Bir başka deyişle profesyonel Kur'ân okuma (Kurralık) kültürü ile mahremiyet kültürü, görme engelliliği bazı durumlarda bir avantaja dönüştürerek bu engele sahip bireyleri değerli roller üstlenebilme imkânlarına kavuşturmaktadır.

\section{Sonuç}

$\mathrm{Bu}$ çalışmada sosyal rollerin farklılıkları sebebiyle kategorize edilen engellilerin sosyal değersizleştirmeye muhatap olma süreçleri, rollerin bireylere sosyal konum tayin etme güçleri üzerinden irdelenirken; Türk toplumunun sosyokültürel hafızasında farklılıkları dışlama gerekçesine dönüştürmek yerine toplumsal ve bireysel faydaya dönüştürme tecrübeleri iki önemli örnek üzerinden ele alınmıştır. Zira işitme engellilerin devlet kurumlarında ve görme engellilerin hafızlık ve diğer dinî hizmetlerde görev almaları engellilik olgusunun sosyokültürel geçmişimizde nasıl anlamlandırıldığı sorusunun cevabına dair önemli ipuçları barındırmaktadır. Engellilik olgusunun sosyokültürel olarak anlamlandırılması konusunda nasıl bir mirasa sahip olduğumuz sorusunun geniş ölçekte cevaplanması bu makalenin ötesinde bir husustur ve başka çalışmalar bakımından bakir bir alan olarak durmaktadır. Ancak bu çalışmada değinilen hususlar Osmanlı toplumunda bedensel farkl1lıkların bir ötekileştirme gerekçesi olarak görülmek bir yana, toplumsal ve bireysel bir fayda ve avantaja dönüştügüünü göstermektedir.

$\mathrm{Bu}$ çalışmada değinilen işitme engellilerin ve görme engellilerin üstlendikleri roller göstermektedir ki, Türk toplumunun sosyokültürel geçmişi açısından yapısalc1-fonksiyonalist rol kuramının önerdiği şekliyle engellilik bireyi edilgen ve çocuksulaştıran bir rol olmadığı gibi, düzeltilmesi gereken bir sorun da değildir. Öte yandan bu çalışmada ele alınan engellilerce üstlenilen örnek uygulamalar engelli bireylerin değerli roller üzerinden toplumsal işleyişin önemli birer aktörü konumunda olduklarını göstermektedir. Hatırlanacağı gibi bu çalışmada işitme engellilerin devlet kurumlarındaki çalışmalarıyla bir ölçüde devletin bekasıyla ilgili bir alan olan istihbârî sahada hizmetlerde bulunduklarına değinilmişti. Benzer şekilde görme engelliler de geçmiş dönem sosyal hayatının merkezinde olan din hizmetlerinde istihdam edilerek hafızlık, kurralık gibi son derece değerli roller üstlenmeleri mümkün olabilmiştir. Günümüz dünyasının bedensel "kusursuzluğu" önceleyen sağlamcı (ablist) anlayışı dikkate alındığında, bedensel farkl1lıkları dolayısıyla değersizleştirilmeleri beklenen bireylerin çok değerli rollere 
muhatap olmaları kayda değer bir durumdur. Zira devlet kurumlarında görev almak ve din hizmetlerinde bulunmak son derece fonksiyonel roller üstlenmek anlamına gelirken, engelliler toplumsal yaşamın merkezinde ve toplumsal düzene katk1 sağlayan bireylere dönüşmüşlerdir. Bu çerçevede saray görevliliği, hafızlık, kurralık gibi değerli roller, engelliliğin birey bakımından bir master rol haline gelmesinin ve sosyal değersizleştirme süreçlerine maruz kalmasının da önüne geçmiş olmaktadır. Osmanlı toplumu sosyal hayatında dinin yeri düşünüldüğünde, hafızlık ve kurralık rollerinin gıpta ile bakılan roller olduğu hatırlanacaktır. Engelli bireylerin böylesine değerli rollerle kimliklenmelerinin bir sonucu olarak, engellilik değersizleştirici bir sembol olmaktan çıkar.

Osmanlıdaki işitme engellilere eğitim veren kurumlar, Topkapı Sarayı bünyesinde işaret dili eğitimi sağlayan bir birim ve görme engellilere hafızlık eğitimi veren Dar-ul-Huffazlar, SRV kuramının vurgulamış olduğu engellilerin rol üstlenme kapasitelerinin geliştirilmesi için uygun bir zeminin sosyokültürel geçmişimizde var olduğuna işaret etmektedir. Bu cümleden olarak, engellilerin toplumsal kaynak ve firsatlara erişebilmelerinin genel anlamda bir sosyal sorun olmadığını söyleyebiliriz. Bu noktada bir hususa dikkat çekmek gerekir ki, bu çalışma Osmanlıda tüm engellilerin değerli rolleri üstlenebildikleri yahut refah seviyesi yüksek bir hayat yaşadıkları iddiasını dillendirmek gibi bir amaca sahip değildir; bu tartışma başka çalışmaların konusu olabilir. Ancak bu çalışmada değinilen örnek uygulamalar göstermektedir ki engellilik değerli roller üstlenebilmek konusunda bir dezavantaj olarak anlaşılmamıştır. Aksine fitrî farklılıklar sadece engelli bireyler için değil, aynı zamanda toplum için de faydaya dönüştürülmüştür. Bu anlayış SRV kuramının değersizleştirilmiş bireylere değerli roller üstlenme kapasitesi kazandırma öngörüsünü daha ileri bir boyutta, fitrî farkl11ıkları faydaya dönüştürme boyutunda realize etmiş olmaktadır. Bununla birlikte SRV kuramının bu çalışmada değinilen önermeleri, sosyokültürel geçmişimizden tevarüs ettiğimiz farklılıkların faydaya dönüştürülmesi paradigmasıyla birlikte günümüz dünyasının "dezavantajlı" olarak addettiği engellilere yönelik sosyal hizmet müdahalelerinin geliştirilmesinde referans bir bakış açısı sunmaktadır.

SRV kuramının önermelerinin uygulama planında toplumsal engellilik algıs1nın geliştirilmesi ve engelli bireylerin rol üstlenme kapasitelerinin geliştirilmesi olmak üzere iki önemli boyutundan söz etmek mümkündür. Öncelikle engelli bireylerin içinde yaşadıkları toplumda değersizleştirici etiketlerle etiketlenmelerinin algisal boyutuna yönelik müdahaleler toplumsal düzeydeki engellilik algısının değişmesinde önemli bir yere sahiptir. Bu çerçevede toplumun değerli 
saydığı rolleri başarıyla icra eden engellilerin görünürlüğü önemli bir araç olarak durmaktadır. Bu meyanda toplumun değerli saydığı rolleri başarıyla icra eden engelli bireylerin görünür hale gelmeleri hem toplumsal düzeydeki engellilik algis1nın gelişmesine; hem de engelli bireyler için rol-model olarak benimsenmelerine yardımcı olacaktır. Bu çerçevede sosyokültürel geçmişimizden devraldığımız fitrî farkl11ıkları ötekileştirme gerekçesi olarak görmeme ve faydaya dönüştürme kültürünün tanıtılması; bu sosyokültürel atmosfer içinde değerli roller üstlenerek temayüz etmiş engellilerin ve üstlendikleri rollerin görünür kılınması önem arz etmektedir. Diğer taraftan eğitim firsatlarından yeterince faydalanamamış engelli bireylerin başta öz bakım ve kişisel yaşam becerileri olmak üzere diğer değerli rolleri üstlenebilme ve icra edebilme yeteneklerinin geliştirilmesine yönelik çalışmalardır. Bu çalışmalar örgün eğitim faaliyetlerine paralel olarak farklı engel gruplarına yönelik özelleştirilmiş bağımsız yaşam becerileri eğitimleriyle güçlendirilmelidir.

Engelli bireylerin değerli sayılan rolleri üstlenme ve icra etme kapasitelerinin geliştirilmesi engelli bireylerin iyilik hallerinin gelişmesi sonucunu doğurmas1nın yanında, toplumu meydana getiren tüm bireylerin farklılıklarla birlikte yaşama kültürünün gelişmesine de katkı sağlayacaktır. 


\section{Kaynakça}

Allen, R. L. - Waks, L., "The Social Reality Construction of Attitudes Toward the Social Roles of Women and African Americans", Howard Journal of Communications, cilt 2, say1 2, 1990; doi: 10.1080/10646179009359711.

Amankwaa, L. C., "Maternal Postpartum Role Collapse as a Theory of Postpartum Depression", The Qualitative Report, cilt 10, say1 1, 2005.

Ang, C. S. - Zaphiris, P., "Social Roles of Players in MMORPG Guilds", Information, Communication \& Society, cilt 13, say1 4, 2010; doi: 10.1080/13691180903266952.

Aubry, T. - Flynn, R. J. - Virley, B. - Neri, J., "Social Role Valorization in Community Mental Health Housing: Does It Contribute To the Community Integration and Life Satisfaction of People With Psychiatric Disabilities?", Journal of Community Psychology, cilt 41, say1 2, 2013.

Aynur, H. Ş., "Başlangıcından Günümüze Kadar İslam Coğrafyasında Hafızlık Tedrisatı", Dinbilimleri Akademik Araştırma Dergisi, cilt 11, sayı 2, 2011.

Balcı, S., Osmanlı Devleti'nde Engelliler ve Engelli Ĕgitimi Dilsiz ve Ama Mektebi, İstanbul, Libra Yayınları, 2013.

Bates, F. L., "Position, Role and Status: A Reformulation of Concepts", Social Forces, cilt 34, say1 4, 1956; doi: 10.2307/2573663.

Beneš, V. - Harnisch S., "Role Theory in Symbolic Interactionism: Czech Republic, Germany and the EU", Cooperation and Conflict, cilt 50, say1 1, 2015; doi: 10.1177/0010836714525768.

Bhutto, S., "Traditional and Modern Methods Used for Memorization of Quran in Turkey", Ma'arif Research Journal, say1 10, 2015.

Biddle, B. J., "Recent Developments in Role Theory", Annual Review of Sociology, cilt 2, say1 1, 1986; doi: 10.1146/annurev.so.12.080186.000435.

Blakely, T. J. - Dziadosz, G. M., "Social Role Theory and Social Role Valorization for Care Management Practice", Care Management Journals, cilt 16, say1 4, 2015; doi: 10.1891/1521-0987.16.4.184.

Burnham, J. C., "The Death of the Sick Role", Social History of Medicine, cilt 25, say1 4, 2012; doi: 10.1093/shm/hks018.

Callero, P. L. - Howard J. A. - Piliavin J. A., "Helping Behavior as Role Behavior: Disclosing Social Structure and History in the Analysis of Prosocial Action", Social Psychology Quarterly, cilt 50, say1 3, 1987. 
Callero, P. L., "Toward A Meadian Conceptualization of Role", The Sociological Quarterly, cilt 27, say1 3, 1986.

Charmaz, K., "Experiencing Stigma and Exclusion: The İnfluence of Neoliberal Perspectives, Practices, and Policies on Living with Chronic İllness and Disability", Symbolic Interaction, cilt 43, say1 1, 2020.

Chilcott, J. H., "Structural Functionalism as a Heuristic Device", Anthropology Education Quarterly, cilt 29, say1 1, 1998; doi: 10.1525/aeq.1998.29.1.103.

Clayton, L., "The Personality Theory of JL Moreno", Group Psychotherapy \& Psychodrama, say1 28, 1975.

Cocks, E., "Normalisation and Social Role Valorisation: Guidance for Human Service Development”, Hong Kong Journal of Psychiatry, cilt 11, say1 1, 2001.

Collier, P. - Callero, P., "Role Theory and Social Cognition: Learning to Think like a Recycler", Self and Identity, cilt 4, say1 1, 2005; doi: $10.1080 / 13576500444000164$.

Dalyan, M. G. - Ünisen, A., "Engelli Eğitimine Alternatif Bir Bakış: Hafızlık Eğitimiyle Görme Engellilere Toplumsal Saygınlık Kazandırılması (Osmanlıdan Cumhuriyete Adıyaman' da Kör Hafizlar)", Route Education and Social Science Journal, say1 12, 2016; doi: 10.17121/ressjournal.570.

Daniels, M. J., "Relational Status and the Role Concept", The Pacific Sociological Review, cilt 2, say1 1, 1959; doi: 10.2307/1388336.

Daukantaitè, D. - Thompson, E. S., "The Relationship Between Identity Consistency Across Social Roles and Different Aspects of Mental Health Varies by Age Group", Identity, cilt 14, say1 2, 2014; doi: 10.1080/15283488.2014.892000.

Dietz, A. - Thiessen, A. - Griffith, J. - Peterson, A. - Sawyer, E. McKelvey, M., "The Renegotiation of Social Roles in Chronic Aphasia: Finding a Voice through AAC", Aphasiology, cilt 27, say1 3, 2013; doi: 10.1080/02687038.2012.725241.

Dorozenko, K. P. - Roberts, L. D. - Bishop, B., "The İdentities and Social Roles of People with an İntellectual Disability: Challenging Dominant Cultural Worldviews, Values and Mythologies", Disability \& Society, cilt 30, say1 9, 2015; doi: 10.1080/09687599.2015.1093461.

Flynn, R. J. - LaPointe, N. - Wolfensberger, W. - Thomas, S., "Quality of Institutional and Community Human Service Programs in Canada and the United States", Journal of Psychiatry and Neuroscience, cilt 16, sayı 3, 1991. 
Gabel, S. - Peters, S., "Presage of a Paradigm Shift? Beyond the Social Model of Disability toward Resistance Theories of Disability", Disability \& Society, cilt 19, say1 6, 2004; doi: 10.1080/0968759042000252515.

Gerhardt, U., "Toward a Critical Analysis of Role", Social Problems, cilt 27, say1 5, 1980; doi: 10.2307/800196.

Gökdemir, A., "Osmanlı Kur’ân Eğitim Merkezleri: Dârulkurrâlar ve Sibyan Mektepleri”, Edebali İslamiyat Dergisi, cilt 1, say1 2, 2017.

Guirguis L. M. - Chewning, B. A., "Role Theory: Literature Review and İmplications for Patient-Pharmacist İnteractions", Research in Social and Administrative Pharmacy, cilt 1, say1 4, 2005; doi:10.1016/j.sapharm.2005.09.006.

Günay, N., "Osmanlı Devleti'nde Engellilerin İstihdamı ve Saray Teşkilatında Dilsizler", Uluslararası Kültürel ve Sosyal Araştırmalar Dergisi (UKSAD), cilt 2, sayı 1, 2016.

Handel, W., "Normative Expectations and the Emergence of Meaning as Solutions to Problems: Convergence of Structural and Interactionist Views", American Journal of Sociology, cilt 84, say1 4, 1979; doi: 10.1086/226864.

Hilbert, R. A., "Toward an İmproved Understanding of "Role", Theory and Society, cilt 10, say1 2, 1981; doi: 10.1007/bf00139892.

Huber, J., "Symbolic İnteractionism as a Pragmatic Perspective: The Bias of Emergent Theory", American Sociological Review, cilt 38, say1 2, 1973; doi: $10.2307 / 2094400$.

İpşirli, M., "Musahiblik", TDV İslâm Ansiklopedisi, cilt 31, İstanbul, TDV Yayınları, 2006.

Jacobs, S., "How Role Replaced Personality as a Major Category of Sociology", The American Sociologist, cilt 49, say1 2, 2017; doi: 10.1007/s12108-0179354-0.

Jakovina, I.Z. - Jakovina, T., "Role Theory and Role Analysis in Psychodrama: A Contribution to Sociology", Socijalna Ekologija, cilt 26, say1 3, 2017; doi: 10.17234 /SocEkol.26.3.5.

Kemaloğlu, Y. - Yaprak-Kemaloğlu, P., "The History of Sign Language and Deaf Education in Turkey”, Kulak Burun Boğaz İhtisas Dergisi, cilt 22, say1 2, 2012; doi: 10.5606/kbbihtisas.2012.013.

Kurt, Y., “Kur'ân'ın Korunmasında Hâfızlık Müessesesi”, Hitit Üniversitesi Ilahiyat Fakültesi Dergisi, cilt 11, say1 22, 2012. 
Lemay, R., "Social Role Valorization Insights into the Social Integration Conundrum", Mental Retardation, cilt 44, say1 1, 2006; doi: 10.1352/0047-6765(2006)44[1:SRVIIT]2.0.CO;2.

Levine, S. - Kozloff, M. A., "The Sick Role: Assessment and Overview", Annual Review of Sociology, cilt 4, say1 1, 1978; doi: 10.1146/annurev. so.04.080178.001533.

LoConto, D. G. - Jones-Pruett, D. L., "Utilizing Symbolic Interactionism to Assist People with Mental Retardation during the Grieving Process. Illness", Crisis \& Loss, cilt 16, say1 1, 2008; doi: 10.2190/11.16.1.b.

Loudfoot, E. M., "The Concept of Social Role". Philosophy of the Social Sciences, cilt 2, say1 1, 1972; doi: 10.1177/004839317200200110.

Lynch, K. D., "Modeling Role Enactment: Linking Role Theory and Social Cognition", Journal for the Theory of Social Behaviour, cilt 37, say1 4, 2007.

Miles, M., "Deaf People, Sign Language \& Communication, In Ottoman \& Modern Turkey: Observations and Excerpts from 1300 to 2009. From sources in English, French, German, Greek, Italian, Latin and Turkish, with İntroduction and Some Annotation", Independent Living Institute, 2009, https://www.independentliving.org/miles200907.html (Erişim Tarihi: 11/02/2021).

, "Signing in the Seraglio: Mutes, Dwarfs and Jestures at the Ottoman Court 1500-1700", Disability \& Society, cilt 15, say1 1, 2000; doi: $10.1080 / 09687590025801$.

Min, S. - Ceballos, L. M. - Yurchisin, J., "Role Power Dynamics within The Bridal Gown Selection Process", Fashion and Textiles, cilt 5, say1 1, 2018; doi: 10.1186/s40691-018-0132-6.

Nureski, D., “Osmanlı'dan Günümüze Makedonya'daki Türk Kültürü ve Makedonya’nın Türk Kültür Tarihindeki Yeri ve Önemi”, Avrasya Etudleri, sayı 50, 2016.

Osburn, J., "An Overview of Social Role Valorization Theory", SRV/VRS: The International Social Role Valorization Journal/La Revue Internationale de la Valorisation des Roles Sociaux, cilt 3, say1 1, 1998.

Pierro, A. - Mannetti, L. - Livi, S., "Self-Identity and the Theory of Planned Behavior in the Prediction of Health Behavior and Leisure Activity", Self and Identity, cilt 2, say1 1, 2003; doi: 10.1080/15298860309024.

Richardson, K., "New Evidence for Early Modern Ottoman Arabic and Turkish Sign Systems", Sign Language Studies, cilt 17, say1 2, 2017; doi: 10.1353/ sls.2017.0001. 
Roe, J. - Joseph, S. - Middleton, H., "Symbolic İnteraction: A Theoretical Approach to Understanding Stigma and Recovery", Mental Health Review Journal, cilt 15, say1 1, 2010; doi:10.5042/mhrj.2010.0200.

Sağlam-Tekir, H., "Toplumsal Hayatta Karşılaştıkları Zorluklarla Osman11 Devleti'nde Sağır, Dilsiz ve Âmâlar”, Osmanlı Mirası Araştırmaları Dergisi (OMAD), cilt 3, say1 7; doi: 10.17822/omad.2016.43.

Scalenghe, S., Disability in the Ottoman Arab World, 1500-1800 (Cambridge Studies in Islamic Civilization), Cambridge, Cambridge University Press, 2014; doi:10.1017/CBO9781107045309.

Segall, S., "The Sick Role Concept: Understanding Illness Behavior", Journal of Health and Social Behavior, cilt 17, say1 2, 1976; doi: 10.2307/2136342.

Serpe, R. T., "Stability and Change in Self: A Structural Symbolic İnteractionist Explanation", Social Psychology Quarterly, say1 50, 1987; doi: $10.2307 / 2786889$.

Sieber, S., "Toward a Theory of Role Accumulation", American Sociological Review, cilt 39, say1 4, 1974; doi: 10.2307/2094422.

Siemieńska, R., "Guest Editor's Introduction: Value Systems and Social Roles in Cross-National Perspective", International Journal of Sociology, cilt 38, say1 4, 2008; doi: 10.2753/ijs0020-7659380400.

Stets, J. E. - Burke, P. J., "Identity Theory and Social Identity Theory", Social Psychology Quarterly, cilt 63, say1 3, 2000.

Stets, J. E., "Role Identities and Person Identities: Gender Identity, Mastery Identity, and Controlling One's Partner", Sociological Perspectives, cilt 38, say1 2, 1995; doi: 10.2307/1389287.

Şimşek, K., “Osmanlı Devleti’nde Engelliler İçin Kullanılan Tabir, Lakap ve Sifatlar", Belgi Dergisi, cilt 2, say1 15, 2018.

Tanyeri, Y., "İzmir School for the Deaf”, Turkish Archives of Otorhinolaryngology, cilt 54, say1 1, 2016.

Thoits, P. A., "Multiple İdentities and Psychological Well-Being: A Reformulation and Test of the Social İsolation Hypothesis", American Sociological Review, cilt 48, say1 2, 1983; doi: 10.2307/2095103.

Tibbetts, P., "Symbolic İnteraction Theory and The Cognitively Disabled: A Neglected Dimension", The American Sociologist, cilt 35, say1 4, 2004; doi: 10.1007/s12108-004-1021-6. 
Turner, R. H., "The Role and the Person”. American Journal of Sociology, say1 84, 1978; doi: 10.1086/226738.

Wolfensberger, W., "A Brief Overview of Social Role Valorization”, Mental Retardation, cilt 38, say1 2, 2000; doi: 10.1352/0047-6765(2000)038<0105:ABOOSR $>2.0 . \mathrm{CO} ; 2$.

, "An "If This, Then That" Formulation of Decisions Related to Social Role Valorization As a Better Way of Interpreting It to People", Intellectual and Developmental Disabilities, cilt 49, say1 6, 2011A; doi: 10.1352/1934-955649.6.456.

, "Social Role Valorization and, or Versus, "Empowerment", Mental Retardation, cilt 40, say1 3, 2002; doi:10.1352/0047-6765(2002)040<0252:srvaov>2.0.co;2.

, "Social Role Valorization and, or Versus, "Empowerment", Intellectual and Developmental Disabilities, cilt 49, say1 6, 2011B; doi: 10.1352/1934-9556-49.6.469.

, "Social Role Valorization: A New Insight, A New Term, for Normalization", Australian Association for the Mentally Retarded Journal, cilt 9, sayı 1, 1985.

, "Social Role Valorization: A Proposed New Term for the Principle of Normalization", Mental Retardation, cilt 21, say1 6, 1983.

Yablonsky, L., "An Operational Theory of Roles", Sociometry, cilt 16, say1 4 , 1953; doi: 10.2307/2785939.

Zurcher, L. A., "Role Selection: The Influence of Internalized Vocabularies of Motive", Symbolic Interaction, cilt 2, say1 2, 1979; doi: 10.1525/si.1979.2.2.45.

\section{Araştırmacıların Katkı Oranı}

Araştırmacıların her birisinin mevcut araştırmaya katkısı $\% 50$ oranındadır.

\section{Çatışma Beyanı}

Araştırmada herhangi bir çıkar çatışması bulunmamaktadır. 
